\title{
Partners No More: Relational Transformation and the Turn to Litigation in Two Conservationist Organizations
}

\section{Noga Morag-Levine}

The rise in litigation against administrative bodies by environmental and other political interest groups worldwide has been explained predominantly through the liberalization of standing doctrines. Under this explanation, termed here "the floodgate model," restrictive standing rules have dammed the flow of suits that groups were otherwise ready and eager to pursue. I examine this hypothesis by analyzing processes of institutional transformation in two conservationist organizations: the Sierra Club in the United States and the Society for the Protection of Nature in Israel (SPNI). Rather than an eagerness to embrace newly available litigation opportunities, as the "floodgate" model would predict, the groups' history reveals a gradual process of transformation marked by internal, largely intergenerational divisions between those who abhorred conflict with state institutions and those who saw such conflict as not only appropriate but necessary to the mission of the group. Furthermore, in contrast to the pluralist interactions that the "floodgate model" imagines, both groups' relations with pertinent agencies in earlier eras better accorded with the partnership-based corporatist paradigm. Sociolegal research has long indicated the importance of relational distance to the transformation of interpersonal disputes. I argue that, at the group level as well, the presence or absence of a (national) partnershipcentered relationship determines propensities to bring political issues to court. As such, well beyond change in groups' legal capacity and resources, current increases in levels of political litigation suggest more fundamental transformations in the structure and meaning of relations between citizen groups and the state.

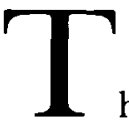

he appearance of political interest groups as litigants in American courts has become so commonplace that it is easy to overlook the relative novelty of this legal-political phenomenon. Although some such groups have relied on litigation at least since the start of the twentieth century, it was only during the 1950s and 1960s that a broad spectrum of interests and a large number of

Address correspondence to Noga Morag-Levine, Department of Political Science, University of Michigan, 6634 Haven Hall, Ann Arbor, MI 48109-1045; e-mail: noga@umich.edu. Many thanks for comments and suggestions on various earlier drafts of this article to Mark Brandon, Cary Coglianese, Hanoch Dagan, Chuck Epp, Martin Edelman, Christine Harrington, Ryan Hudson, Joseph Sanders, Alon Tal, Shemaryahu Talmon, the anonymous reviewers, and, as always, Jonathan Levine.

Law \& Society Review, Volume 37, Number 2 (2003)

(C) 2003 by The Law and Society Association. All rights reserved. 
political organizations turned to the courts (Epstein \& Kobylka 1992; Koshner 1998). Several decades later, interest groups elsewhere in the world have now begun to follow suit, heralding a global judicialization of political disputes (Tate \& Vallinder 1995). While this trend has been widely diagnosed, little research has focused on what accounts for such differences in the litigation propensity of groups over time. This study considers this issue by analyzing processes of institutional transformation in two conservationist organizations: the Sierra Club in the United States and the Society for the Protection of Nature in Israel (SPNI).

The history of environmental interest group litigation in the United States is among the most evident examples of transformation in the salience of law and courts to the agenda of political groups. Until the 1960s, environmental lawsuits in America were, by and large, limited to nuisance disputes concerning pollution and other interferences with private rights; the practice of legal challenges by environmental groups to administrative policies, which would later become a central pillar of American environmental activism, did not then exist. Yet by the later 1960s, two categories of environmental organizations began to bring legal challenges of this type. The first was new groups, such as the Environmental Defense Fund (EDF) and Natural Resources Defense Council (NRDC), that were created in large part for the purpose of launching such legal mobilization. The second category consisted of longstanding conservationist organizations, such as the Sierra Club, that now added litigation strategies to their repertoire. A parallel pattern is evident in Israel, where environmental litigation on the part of interest groups was exceedingly rare until the 1990s. Behind the growth in levels of environmental lawsuits since then stand both the Israel Union for Environmental Defense, an NRDC-modeled group that was created in 1991 (Morag-Levine 2001), and SPNI, an established conservationist organization akin to the Sierra Club. Both groups thus represent organizations whose strategies came over time to include litigation against agencies. In this they offer especially useful cases for examining the origins of change in use of litigation by interest groups. This is because it is through in-depth analysis of the history of these groups that one can discern what prevented conservationist organizations from bringing legal actions against agencies earlier, and consequently, what manner of change precipitated the groups' subsequent transformation in this respect.

To the extent that these intertwined questions have been addressed previously, the predominant response has highlighted changes in the groups' capacity to litigate. This argument ascribes this enhanced capacity both to growth in foundation-based financial support for litigation (Berry 1977) and, most important, 
the liberalization of narrow standing doctrines that had previously demanded demonstration of specific injury to the group or its members as a precondition to challenging administrative decisions in court (e.g., Orren 1976; Harris \& Milkis 1996; Hjelmar 1996). In this connection, the liberalization of standing has meant both the creation of greater opportunities for citizen group participation in hearings conducted by administrative agencies and the right of these groups subsequently to challenge these decisions in court.

The turning point, under this view, came once the courts reversed their earlier restrictive doctrines in this regard, most famously in the 2nd Circuit's decision in Scenic Hudson (1965) that an ad hoc group of local citizens and clubs did indeed have the standing to challenge, as "private attorneys general," a license to construct an electric generating system on Storm King Mountain in New York's upper Hudson Valley. In a similar vein, Dotan and Hofnung (2001) stress the link between the Israeli Supreme Court's drastic expansion of groups' standing to sue and growth in levels of interest group litigation during the 1990s.

The hypothesis that the liberalization of standing will trigger a surge in interest group litigation can be thought of as a "floodgate" model under which restrictive standing rules have dammed the flow of suits that groups were otherwise ready and eager to pursue. According to this argument, environmental groups failed to litigate in earlier eras because they could not satisfy judicial requirements that they show direct injury to themselves or their members. With the relaxation of these demands, such groups acquired the hitherto missing legal capacity to challenge administrative decisions. The removal of external barriers - rather than internal transformations in the groups' desire to launch legal suits - is, within this framework, a key explanation for differences in the litigation propensity of political groups over time.

In its emphasis on change in legal capacity, the floodgate model accords with the predominant explanation regarding current sources of variation in the litigation propensity of interest groups. Within this line of scholarship, differences in financial, legal, and other organizational resources serve as the principal explanation for whether, and with what frequency, groups opt to litigate (Epstein 1985; Olson 1990; Scheppele \& Walker 1991). The propensity to litigate is thus thought to increase with the amount of a group's power and resources. A competing view, known as the "political disadvantage theory," conceives of litigation as the instrument of groups lacking the necessary access or resources for successful pursuit of their goals through other political channels (Cortner 1968). In other words, this theory suggests an inverse correlation between a group's political power and its propensity to litigate. The theory was based in large part on the example of the 
National Association for the Advancement of Colored People (NAACP) and the model of litigation that it pioneered, but it could explain only a small fraction of the universe of interest group litigation with the adoption of this strategy by a large number of "advantaged" groups. As Scheppele and Walker (1991) show, by the 1980s, "insider" American interest groups were almost as likely to litigate as "outsider" ones, although the prospect of future interactions and cooperation was seen as a potential barrier to some interest group lawsuits. Yet the extent to which this represented a shift from an earlier era when insider political organizations were unlikely to file suit has not been a focus of this body of political science work.

In attending to the groups' outsider or insider status, Scheppele and Walker build on a rich sociolegal tradition regarding the impact of relational structures on individuals' propensity to litigate. A central tenet of this research tradition is that to understand differences in the transformation of interpersonal disputes, we must look first to the structure of relations between the parties, rather than their legal and financial capacity to litigate (Macaulay 1963; Engel 1984; Ellickson 1991; Greenhouse 1986; Hamilton \& Sanders 1992). In other words, whether a particular private dispute will end in court depends only in part on the existence of a legal cause of action and the means to pursue it. More fundamentally, it is the structure and meaning of the pertinent relationship that determine the trajectory of processes of dispute transformation. Under this view, litigation is incompatible with the maintenance of what are termed here partnership relations, that is, relations based on shared interests, identity, and/or affective bonds. Conversely, resort to litigation signals an absence, or breakdown, of any such partnership.

In contrast to this sociolegal perspective, studies of interest group litigation have generally ignored the relevance of parallel processes of transformation in the identity of groups and their relations with administrative agencies. An a priori assumption regarding the inherent absence of partnership between interest groups and the agencies they seek to influence has discouraged attention to the role of relational transformation in bringing about litigation by interest groups. This assumption derives, in turn, from pluralist-inspired conceptions of the behavior and role of interest groups. Partnership relations entail some manner of overarching shared purpose to which partners are expected to subsume conflicting interests. Yet the very absence of any such collective national enterprise is a starting premise of the pluralist paradigm. "In developing a group interpretation of politics," Truman writes, "we do not need to account for a totally inclusive interest, because one does not exist" (1971:51). Under this assumption, there would 
be no basis for expecting deference by groups toward the priorities and decisions of the state. On the contrary, it is the process of unencumbered competition between self-interested groups that defines and serves the common good. By definition, whether such groups will opt to sue the state will depend on their legal capacity and prospects for success, rather than underlying relational constraints.

Implicit to the floodgate model is the assumption that the groups have fit the pluralist mold all along, i.e., that litigation, long before the floodgates opened, has been seen as an appropriate strategy consistent with the groups' ideology and sense of mission. The relevant change, in other words, has been external to the groups. However, one cannot a priori assume the groups' longstanding pluralist identity in view of the counter-example of corporatist modes of political organization, a mode associated with western European countries but common across many regions of the world (Schmitter 1974; Williamson 1989; Lijphart \& Crepaz 1991; Wiarda 1997). Unlike their pluralist counterparts, corporatist groups are often licensed, recognized, and even subsidized by the state (Schmitter 1974). Furthermore, in contrast to pluralism's rejection of notions of an inclusive national interest, "corporatism requires of each interest group that it at least suspend, if not eliminate, commitment to its own well-being in favor of a more public good" (Zeigler 1988:69). Katzenstein refers to this corporatist phenomenon as an ideology of "social partnership" between political organizations and state institutions (1985:32).

As has been shown repeatedly, legal challenges to administrative decisions tend to be less frequent within corporatist systems, such as exist in Germany, France, Sweden, and even Britain, than in the paradigmatically pluralist United States (e.g., Kelman 1981; Brickman, Jasanoff, \& Ilgen 1985; Vogel 1986; Sellers 1995; Kagan \& Axelrad 2000; Kagan 2001). Narrow standing rules (typical of corporatist systems) provide partial explanation for this divergence. However, two arguments suggest that these rules are not in and of themselves sufficient to explain this difference. The first is the relative scarcity of litigation within corporatist systems, even by entities and groups unaffected by narrow standing doctrines (such as business organizations that might otherwise challenge policies that directly impinge on their interests) (Brickman, Jasanoff, \& Ilgen 1985; Sellers 1995). The second counter-argument to the standing-based hypothesis derives from larger patterns of collaboration within corporatist regimes between bureaucracies and interest groups (Zeigler 1988). Well beyond litigation, corporatist groups tend to avoid all manner of explicit conflict with the state, an aversion that cannot logically be attributed to standing doctrines as these have no relevance to adversarial tools beyond the realm of 
the courts. And, in fact, one might argue that these doctrines can themselves be seen as derivative of governing partnership ideologies and attendant conceptions of the proper purpose of political groups. From this perspective, one can see both the expansion of standing and groups' embrace of litigation as the product of a larger pluralist transformation and the decline of earlier partnership ideologies within and outside the groups.

In examining the potential impact of any such partnership ideology, the pertinent question is not about the actual existence of any such overarching national interest or the validity of demands that groups subsume particularistic goals to collective ones. Rather, it is whether relevant actors construe their relationship with the state in terms of such an obligation. As March and Olsen explain, institutions can define the domain of "appropriate" action, which in turn shapes political behavior (1989:38). Discerning this process demands a methodology that closely attends to such groups' own understandings of their purposes, identities, and sense of membership over time (e.g., Thelen \& Steinmo 1992; Orren \& Skowronek 1995; Powell 1991).

In particular, the behavior of groups before and after a significant widening of legal opportunities to sue can illuminate the relative roles of tactics and ideology in determining groups' adoption or rejection of litigation as a strategy for political mobilization. However, an exclusive focus on this moment of transformation is insufficient due to the possibility that organizational inertia or habits might delay the adoption of newly available litigation opportunities by established groups. Consequently, disentangling the potentially circular link between groups' capacity and desire to litigate requires analysis of the place within their organizational repertoire of adversarial strategies, other than litigation, over time.

This study undertakes this task with regard to the Sierra Club and SPNI, two groups whose history spans a sharp move toward interest-group pluralism and liberalization of standing doctrines in their respective national locales. The article focuses on the response of these organizations to the change. Rather than an eagerness to embrace newly available litigation opportunities, as the floodgate model would predict, the groups' history reveals a gradual process of transformation marked by internal, largely intergenerational, divisions between those who abhorred conflict with state institutions and those who saw such conflict as not only appropriate but necessary to the mission of the group, which had been recast in a pluralist mold. The reformulation of each organization as an adversarially oriented interest group-a necessary precursor to the adoption of political litigation as an organizational strategy-was precipitated by a pluralist shift in the 
larger political environment of the two societies. I argue that in parallel to the transformation of interpersonal disputes, at the group level as well, the presence or absence of a (national) partnership-centered relationship determines propensities to bring political issues to court. As such, well beyond change in groups' legal capacity and resources, current increases in levels of political litigation suggest more fundamental transformations in the structure and meaning of relations between citizen groups and the state.

\section{Liberalized Standing and Reluctant Litigants}

The rush of environmental litigation that followed in the wake of Scenic Hudson (1965)-most importantly through the creation of the NRDC and EDF - supports the case's import in precipitating new forms of environmental and other interest group litigation. But the evident increase in environmental litigation subsequent to the case does not in and of itself establish that it was for lack of standing that environmental groups failed to pursue litigation strategies up to that point. On the contrary, the prominent role of new environmental organizations in the promotion of environmental lawsuits suggests reluctance on the part of the established conservationist organizations to embrace newly available opportunities for legal action. In fact, as the circumstances surrounding the creation of the EDF suggest, it was partially in response to this ambivalence that the new environmental law organizations were created in the first place. The group of New Yorkers who ultimately established the EDF began with the idea of forming a litigation arm within the Audubon Society, a traditional conservationist organization established in 1896. The Audubon's leadership, however, rejected the proposal under the argument that "an activistoriented litigation effort had no place within this traditional protectionist organization" (Gottlieb 1993:138).

Outside of the United States, the Audubon Society's failure to exhibit predicted floodgate behavior finds a parallel in the lackluster response of Indian groups to a far-reaching liberalization of standing and outright encouragement of citizen suits on the part of that country's supreme court (Epp 1998). The paucity of rights litigation in India is further puzzling in light of the existence of a wealth of Indian civic associations with ample material capacity to bring and support civil rights litigation (Epp 1998). In explanation, Epp highlights the impact of fragmentation among Indian civil rights organizations, their excessive dependence on charismatic leaders, and the structure of the Indian legal profession. But, at least with respect to Indian women's groups, he offers that the 
marginality of litigation has been, in part, the result of the groups' failure to appreciate its "potentially great importance" (1998:108). In other words, the groups have lacked desire, rather than the capacity to litigate.

Moving beyond public interest litigation, Sellers (1995) has documented reluctance on the part of proponents of development projects in France and Germany, relative to the United States, to advance their agendas through the courts, notwithstanding their ample legal and financial capacity to litigate. Sellers attributes this phenomenon primarily to differences in the incentives that builders in the European and American cases face: European construction firms have both more to gain from close cooperation with the more insulated, corporatist, official networks of Europe and more to lose if they do not cooperate. The differences in the relevant incentive structure derive in turn from the divergent "institutional and normative constraints" and alternative "traditions of public law" in which European and American developers operate (1995:493).

The common denominator across the examples above is a reluctance to exercise available and seemingly promising opportunities to litigate. While this is puzzling when viewed from a pluralist perspective, it is consistent with the sociolegal perspective described in the next section.

\section{Partnership and Litigation}

In his seminal analysis of relational influences on litigation, Macaulay (1963) observed that the most commonly litigated business contract disputes are those brought by terminated franchise owners who have no future relationship to jeopardize. Ongoing business relations are incompatible with litigation because "[t]o file a suit or even to threaten to do so is to imply that the situation of the parties has changed from one in which their interests are congruent - hence the original agreement - to one that is fraught with conflict" (Lempert \& Sanders 1986:228). Even in the business world, which is ostensibly built on purely economic (and highly competitive!) calculations, there appears to be an expectation of reasonably shared interests as a precondition for trade. Litigation explicitly contradicts this assumption, and therein lies its incompatibility with all manner of partnership relations.

As employed here, the term partnership can, but need not, connote a formal agreement of any sort. Instead, it stands for a joint enterprise linking two or more people in pursuit of aggregate rather than individual goals. The enterprise at the center of such partnerships may be a family, friendship, business, or, as argued 
here, a nation. Though clearly different in their goals and the nature of the attachments they embody, a condition of membership in all such collective constructs is a willingness to subsume pertinent individual goals to those of the relevant partnership. Close personal contact is neither a necessary nor a sufficient condition for such partnership relations; rather, the decisive element is the expectation of congruence between interests, or a sharing of a common identity or membership within a larger entity.

As such, the concept of partnership, as employed here, does not overlap with "the principle of relational distance," which argues that there exists an inverse correlation between the degree of closeness between a set of parties and the likelihood that a dispute between them will come before a court (Black 1976). Although partnership relations frequently entail close personal contact, the meaning of the relationship and the extent that it depends on assumptions of shared interests distinguish partnerships from other relational structures. The difference between relational closeness and partnership may be clarified through instances of relational closeness without partnership, and, conversely, of partnership independent of personal relations. An example of interpersonal and professional relations that are devoid of such partnership and thus compatible with litigation is the close and ongoing contact between environmental and business interest groups and the U.S. Environmental Protection Agency (EPA). As Coglianese (1996) shows, in apparent contradiction of the principle of relational distance, litigation is a regular fixture of ongoing and quite personal relationships between these groups and the agency. Rather than "a last-resort strategy reserved for outsiders," litigation in the EPA is "a legitimate institutional process for carrying on business as usual" (1996:759). Coglianese argues that this difference results primarily from the relatively unobtrusive and bargaining-friendly nature of litigation against the EPA. But, in addition, he points out the need for a more nuanced analysis of the compatibility of different categories of relationships with litigation. The partnership framework offered here would suggest that the coexistence of litigation with ongoing relations in this administrative context is made possible by the absence of an assumption of converging interests, or institutional norms of partnership, between interest groups and the EPA. ${ }^{1}$

The converse-partnership relations devoid of personal connection-appears to account for the often-noted consensualism

${ }^{1}$ Litigation by groups against the EPA and other administrative agencies can also constitute a cooperative strategy when it aims to provide the agency with political cover for controversial policies or additional resources (O'Leary 1993:117; Rosenberg 1991). In such instances, there exists a confluence of interests between agencies and groups, but no partnership. 
that characterizes dispute resolution practices in Japan. The Japanese propensity to bypass litigation in favor of extrajudicial (and less adversarial) modes of dispute resolution has been attributed alternatively to cultural factors (Kawashima 1963) and to institutional capacity. On the cultural side stand those who argue that a deeply embedded aversion to all manner of overt conflict-a view of litigation as a moral and social wrong-renders the Japanese reluctant to litigate even when suing is within their means and self-interest would seem to dictate in its favor. On the other side stand those who reject culture as an independent explanation, arguing that such theories implicitly (and implausibly) assume the relative prevalence of seemingly irrational or hyper-altruistic behavior in Japan. Accordingly, they refer dismissively to "the myth of the reluctant litigant" (Haley 1978), instead attributing the Japanese pattern to a scarcity of lawyers and other institutional and structural constraints (e.g., Haley 1978; Ramseyer 1988).

In an effort to bridge this division, Hamilton and Sanders (1992) put neither culture nor institutions at the center, highlighting instead the structure of relations. Compared to the United States, Japanese relations are marked by greater hierarchy and solidarity, and prevalent understandings of individual responsibility and mutual obligation vary in a similar fashion:

In the United States, the person tends to be perceived by self and others as an individual whose identity and sense of self stand apart from the group or the community; in Japan, the person tends to be perceived by self and others as a social participant whose identity is in large part defined by social relationships. (Hamilton \& Sanders 1992:49)

In the Japanese context, these social relations refer to membership in the larger "group or community" - an entity extending well beyond one's immediate circle. As such, the apparent paradox of Japanese avoidance of litigation is puzzling only if one fails to recognize that these non-face-to-face associations may be partnership relations nevertheless.

Particularly important in this regard is not simply the decision not to litigate, but also more fundamental processes of injury definition and perception. Japan's more contextual conceptions of the individual, it appears, help shape the manner in which people assign responsibility and blame in the first place. In making this argument, Hamilton and Sanders (1992) build on the insight that litigation is but the end point of a multi-step process of dispute transformation ranging from an initial perception of injury ("naming") to the attribution of responsibility ("blaming") and finally to the articulation of demands for legal redress ("claiming") (Felstiner, Abel, \& Sarat 1980-1981). For this reason, the roots of 
disputing differences more visibly lie in varying propensities to name and voice injuries.

Partnerships affect the trajectory of potential disputes most evidently at the claiming stage because people who articulate a separate interest jeopardize their partner status. But unless we opt to view all partnerships as strictly instrumental means of pursuing exogenously derived interests, partnerships also affect the way in which individuals understand their interests. The meaning of a potentially injurious action is not strictly a function of some objective measure of harm but is conditioned by the identity of the actors and the nature of the relations between them; naming and claiming processes are inevitably interconnected, because what counts as an injury is in large measure defined by what ought to count as such within particular relational frameworks. Consider the example of children picking fruit off my backyard trees within a close-knit community. The reason I avoid confrontation with them is not transparent to the outside observer. Perhaps I am aggravated, but take no action so as not to harm neighborly relations; alternatively, I may be neutral or even pleased at the opportunity to share with my neighbors' children, invited or uninvited. In contrast, I would almost certainly perceive uninvited sharing initiated by strangers as an affront, whether I chose to confront it or not.

Engel (1984) shows how this phenomenon might lead to differences in patterns of disputing between old-timers and newcomers in a rural Midwestern county. For the most part, those in Engel's study who responded to personal injuries with tort lawsuits were outsiders to the community whose reliance on litigation in part was due to their exclusion from relational networks, which insiders could access in lieu of judicial intervention. More profoundly, however, outsiders were more willing to bring personal injury lawsuits because they construed as remediable legal violations events that insiders attributed to inevitable accidents and personal bad luck. (At the same time, established members of the community had little compunction about bringing lawsuits concerning contract violations against outsiders.) Thus differences in legal claiming originated with divergent constructions of injury, responsibility, and appropriate redress.

Under axiomatic pluralist understandings regarding the absence of partnership between political groups and the state, there would be little reason to assume the relevance of parallel processes of injury (or problem) definition and notions of appropriate redress to groups' decisions to litigate. In contrast, if one allows for variation in group definition under alternative systems - and over time - the parallelism (or its absence) between factors conditioning individual and group-level litigation become a matter for empirical inquiry. 


\section{Corporatism, Pluralism, and Relational Transformation}

For American political science after World War II, the pluralist tradition "became both the empirical account and normative vision of American politics" (Petracca 1992:5). Within this account, the historical processes behind the ascendance of the pluralist paradigm were pushed aside, together with the paradigm's relative novelty. But as a number of historical works suggest, competitive and adversarial interest groups are of relatively recent vintage, even in the United States. During the first decade of the twentieth century, the word " interests' was regularly printed with a capital $I$ and uttered in tones of moral outrage," and "as late as the 1920s in the United States, the organized pursuit of group interests was hotly condemned" (Clemens 1997:7). This condemnation reproached the use of politics to achieve sectarian goals rather than the common good, which was viewed as the proper end of politics. The beginnings of alternative, group-based conceptions of the state in American political science date at least to Bentley (1967 [1908]). But it was the rise of European fascism during the 1930s that brought home the evident dangers of the "national partnership state" and moved the reigning American political paradigm from metaphysical conceptions of national unity into a "a buzzing, bewildering plurality of groups" (Rodgers 1987:178). In the process, "interests" transformed from "a mud-stained term of opprobrium" into "the whole of politics" (Rodgers 1987:178).

Until this transformation, domestic political organizations had operated in a vastly different ideological environment regarding their proper relationship with state institutions. The United States of the Progressive Era could not properly be termed corporatist, but it nevertheless shared with the corporatist paradigm a view of the state as protector of the common good, and of political organizations as its partner in this endeavor. The history of groups created during that era, such as the Sierra Club, spans a transformation of this ideology that changed the structure of their relationship with the state. The link between this structural change and the group's subsequent turn to litigation is the focus of the analysis below.

If historical distance creates the illusion in the United States of an unbroken pluralist heritage, the recentness of the shift in Israel has allowed contemporary observers to witness it firsthand. A civil society, autonomous from the state and its institutions, can hardly be said to have existed in Israel until the 1980s (Migdal 1993). As late as 1993, Israeli political scientists described the Israeli political arena as one in which "groups do not provide a key link between the people and their government and groups do not 
compete with one another" (Arian 1993:185). Instead, organized interests exhibited deference to "the national interest over the needs of the individual; the commitment to pursue the welfare of the nation and to make individual sacrifices in order to advance collective ends" (Yishai 1991:362).

This pattern changed during the 1990 s with the establishment of thousands of new associations whose agendas were independent from and, at times, even adverse to those of the state (Peretz \& Doron 1997). An important impetus behind the rapid growth in the number of Israeli associations was the initiative, guidance, and, most important, funding provided by American (often Jewish) foundations, of which the most significant has been the New Israel Fund (NIF). Through its support for the Association for Civil Rights in Israel (ACRI) and other such groups, the NIF sought to increase reliance on litigation as one of its primary goals. ${ }^{2}$ In the environmental sector, the SPNI's existence pre-dated this pluralist transformation, providing a case comparable to that of the Sierra Club in the United States and making it an ideal candidate for a study of the relationship between corporatist partnership ideologies (and their decline) and interest groups' propensity to litigate.

Located on opposite sides of the globe and established almost sixty years apart (the Sierra Club was created in 1892, SPNI in 1954), these two groups nevertheless evolved along similar trajectories. Intimately linked at their inception to the political establishments of their respective countries, the Sierra Club and SPNI shared a similarly consensualist orientation for decades after their founding. This was most evident in the cooperative tenor of relations between the two groups and state administrative agencies; essentially absent from their organizational repertoires was not only litigation but also most other forms of overt challenge to governmental policy. Over the course of the 1950s and 1960s, the Sierra Club gradually assumed an increasingly adversarial stance in its dealings with administrative agencies, and by the end of the 1960 s it began to bring its disputes with these agencies before the courts. SPNI underwent largely similar processes of transformation during the 1990s.

As the most established and financially secure conservationist groups in their respective countries, they were nominally the best positioned to make use of new opportunities for litigation, as these arose. If the change in legal opportunities were the primary factor

${ }^{2}$ In an effort begun in the mid-1980s to help staff these organizations and create a cadre of Israeli civil rights attorneys, the NIF annually sends recent graduates of Israeli law schools to the United States under a program that combines advanced legal education with internships at various public interest law groups. Upon their return, these attorneys are funded for one year, during which they are expected to work within a public interest organization in Israel. 
influencing litigation behavior, one would have expected established, well-funded organizations such as these to be the ones taking up the gauntlet as soon as they acquired standing. The extent to which they resisted, equivocated, or rushed to embrace the adversarial strategies made possible by the opportunity structures of their newly pluralist political environment can illuminate the respective place of both external and internal barriers, in preventing these organizations from legally challenging agencies until then.

\section{Institutional Transformation in the Sierra Club: 1892-1972}

Under the title "New Standing for the Environment," the Sierra Club Bulletin in 1973 credited a then-recent rise in environmental lawsuits to the Scenic Hudson case (Cannon 1973:14). The 1965 case, the article went on to explain, had provided the "breakthrough for the Club and all environmentalists" (Cannon 1973:14). Earlier, "the Club's standing to sue was continually and vigorously challenged by the defendants, and federal agencies were free to ignore conservationist challenges to their decisions" (Cannon 1973:14). With this barrier removed, "the Sierra Club was quick to broaden its strategy, and within a few years after Storm King, the Club was actively paralleling its traditional legislative programs with enforcement proceedings in the courts" (Cannon 1973:14).

Accounts such as this one, offered by members of the groups themselves, helped entrench the floodgate model as an empirical reality in the minds of both environmental activists and observers of the environmental movement. Against the pluralist backdrop of 1970 s environmental politics, unfavorable standing doctrines offered a reasonable retrospective explanation for what by then looked like a perplexing delay in the employment of such suits. But this post hoc reasoning may reveal more about the Sierra Club's redefined mission and organizational identity than it does about its propensity to litigate in an earlier era. For the Club's standing to be "continually . . . challenged by the defendants," there would have had to be multiple attempts at litigation prior to Scenic Hudson. This was not the case. With one exception, a 1962 case that it agreed to join, it was only after Scenic Hudson that the Club began to bring conservationist lawsuits. This is not to suggest that the path to the court was unimpeded prior to Scenic Hudson, as the failure of the 1962 case on standing grounds attests. But this failure cannot per se suffice to explain the absence of any other Sierra Club lawsuits up to this point. As such, it remains to be explored what stopped the Sierra Club from launching such challenges earlier on. The 
following section documents the activities and internal debates of the Sierra Club from its founding to the early 1970s in order to understand the roots of its early refraining from litigation, as well as its later embrace of the strategy. ${ }^{3}$

\section{2: A Sierra's “Alpine Club”}

During the 1880s, Joachim Henry Senger, a German-born professor at the University of California, took steps to organize "an alpine club for mountain lovers" (Wilkins 1995:184). Senger later invited John Muir to join in forming the organization that in 1892 would become the Sierra Club (Wilkins 1995:184).

"Alpine clubs" devoted to various forms of outdoors recreation proliferated in nineteenth-century Germany, in parallel with various scientific societies devoted to the study of nature. Both the recreation-oriented and the scientific groups were expressions of the larger Naturschutz, or nature protection movement, which grew and flourished with the financial and political support of the recently unified German state. The Naturschutz movement also aided directly in state-building in its push for the creation of state conservationist agencies, the first of which was established in Bavaria during the 1860s (Dominick 1992).

The latter third of the nineteenth century was a period of ongoing U.S.-German exchange, particularly through American students who traveled to Germany in large numbers for their graduate studies (Rodgers 1998). They and German émigrés such as Senger were most likely the conduit through which local hiking and mountain climbing organizations sprouted, beginning with the Williamson Alpine Club in 1863. Other such groups followed in Portland (Maine), Colorado Springs, and Boston, where the Appalachian Mountain Club was established in 1875 (Jones 1965). The Sierra Club built on these earlier precedents but innovated in its explicit inclusion of conservation within its organizational goals. This emphasis derived in large part from the influence of John Muir.

John Muir, who arrived in California in 1868, spent much of the following decade traveling and writing about the geology, flora,

3 Analysis of the Club's development up to the 1950 s relies (primarily) on two books written by historians closely associated with the organization: Jones (1965) and especially Cohen (1988). The account of the Club's development between 1950 and 1972 relies, in addition to Cohen and other secondary sources, on a review of the Sierra Club Bulletin during that period, in addition to the following volumes in the Sierra Club Oral History Series: Sierra Club President, 1991-1992: The Club, The Legal Defense Fund, and Leadership Issues, 1984-1993, by Phillip Berry, 1997; Environmental Activist, Publicist, and Prophet, by David Brower, 1980; Mountaineer, Lauyer, Environmentalist, by Richard Leonard, 1975; and Sierra Club Executive Director: The Evolving Club and the Environmental Movement, by Michael McCloskey, 1983. 
and awe-inspiring beauty of the Sierra Nevada mountains. During that time, he also forged a close friendship with Robert Underwood Johnson, an editor for Century Magazine. In 1889, they jointly promoted the creation of a national park in the territory surrounding the California state park that had been established in Yosemite Valley during the 1860s. In 1891, Johnson encouraged Muir and other of his associates to form a "defense association" for the protection of the newly created Yellowstone and Yosemite national parks (Jones 1965:8). Muir's interest in this goal led him to respond favorably to Senger's invitation in spring 1892 that he "was greatly interested in the formation of an Alpine club" (Jones 1965:9).

The group thus emerged from the overlapping agendas of two sets of leaders. The first, including Senger and Warren Olney (a lawyer who would later become the mayor of Oakland, California), was primarily interested in camaraderie and outdoor recreation. The second, composed of John Muir (and supported by Robert Underwood Johnson), was committed to the protection of Yosemite National Park, whose mountains the solitary Muir generally preferred to hike alone. These divergent agendas are reflected in the Club's articles of incorporation, which Olney drafted and twenty-seven charter members signed on June 4, 1892. These articles outline a hierarchy of three organizational goals:

To explore, enjoy and render accessible the mountain regions of the Pacific Coast; to publish authentic information concerning them; and to enlist the support and cooperation of the people and the government in preserving the forests and other natural features of the Sierra Nevada Mountains. (Cohen 1988:9)

The central agenda of the conservationist movement during the Progressive Era was a greater federal role in the protection of scenic areas, through the creation of federal forest reserves and new federal agencies to oversee them (Andrews 1999:144). Within this framework, private conservationist organizations existed to promote the formation of such administrative bodies and to provide them with assistance after their establishment. The prevalence of natural scientists among the Sierra Club's charter members and those who joined it during its first two decades was relevant to this task. They had expertise about nature, which presumably legitimated their role as consultants to government on matters of conservation. In similar fashion, hiking provided a different kind of claim to expertise through firsthand familiarity with the areas that group members sought to protect. The recreational and conservationist goals were thus complementary, though for the majority of those who joined the Sierra Club during 
the $1890 \mathrm{~s}$, and for decades hence, it was the hiking and social opportunities that seemed to hold the greatest appeal.

Following the example of similar groups, such as the Appalachian Mountain Club, the Sierra Club initiated in 1901 a tradition of annual "high trips" to Yosemite and other destinations in the Sierra Nevada mountains (Fox 1985; Cohen 1988). The outings, which lasted for several weeks, soon became a central aspect of organizational identity, traditions, and leadership development. The spirit of these events, and the extent to which they defined the experience of membership in the Club, are captured in one participant's account:

The Sierra Club has great and noble purposes, for which we honor it, but besides these its name has come to mean an ideal to us. It means comradeship and chivalry, simplicity and joyousness, and the care-free life of the open. (Fox 1985:120)

The outdoorsy camaraderie sat easily with the group's underlying consensualist orientation in public policy matters.

The group's consensualism was aided by the governing concept of "mixed use," which during this time served as the organizing principle regarding federal management of forest reserves. Federal forest reserves were to serve a diverse, at times competing, set of purposes: logging, grazing, mining, watershed protection, wildlife habitat, and recreation. The federal government's task in this connection was to balance immediate economic interests in development against long-term resource management concerns (Andrews 1999). This formulation, by definition, allowed and even required compromise between economic development and nature preservation agendas under an overarching utilitarian rationale. As Muir himself wrote in 1895, forests, "like perennial fountains, may be made to yield a sure harvest of timber, while at the same time all their far-reaching uses may be maintained unimpaired" (Muir 1895). Yet within a few months of the Sierra Club's establishment, the hidden strains within the mixed-use framework and the limits of consensual conservationist work would become evident to Muir, first in connection with tourist development in Yosemite Valley, and then most dramatically in the Hetch Hetchy controversy.

\section{Yosemite Valley: National Conservation and Local "Interests"}

As discussed, Progressive Era conservationists saw their goal in terms of expanding the role of the federal government in natural resource management, relative to the place of state and local authority. Thus whereas the federal government was the implicit partner, two sets of potential adversaries existed: commercial 
interests that wanted to develop the areas and state and local governments that often supported such development. This conflict quickly became evident in connection with the defense of Yosemite National Park, the first and primary conservationist purpose Muir envisioned for the Sierra Club. The campaign ultimately resulted in the State of California ceding its control over Yosemite Valley to the federal government.

Under the management of a state commission appointed to oversee Yosemite Valley, animal grazing and other land uses directed at serving a growing number of tourists were a source of increasing concern to conservationists by the 1880s. Among the most vocal critics of these policies was Charles D. Robinson, an artist and Sierra Club charter member who, within weeks of the Club's incorporation, urged that it take action on the issue by lobbying the California legislature to cede control of the area that would then become a national park. Whereas Muir was sympathetic to Robinson's agenda, the Club's board of directors initially refused to go along (Jones 1965:58). As Club leaders such as Vice President Warren Olney explained, "the Club would lose prestige if it seemed to resist California's aspirations" (Cohen 1988:14). Rather than pushing for the Valley's recession, it was preferable for the Club to opt for a consultative role and a cooperative relationship with the state commission (Jones 1965; Cohen 1988). A self-described "crank" who successfully pushed for a legislative investigation of the commission during the $1880 \mathrm{~s}$, Robinson soon lost patience with the Sierra Club's lackluster response. ${ }^{4}$ In October 1892, he wrote: "The Sierra Club . . has a mere existence for its own pleasure - that is all .... In short the Club, like the state, is nerveless and dead regarding Yosemite" (Jones 1965:57). Robinson's determination helped put the recession issue on the reluctant Club's agenda, but his "devil may care right or wrong style" failed to gain a following (Jones 1965:37). ${ }^{5}$

Toward the end of the $1890 \mathrm{~s}$, the idea of a unified, federally managed Yosemite park gained broader support within the state, and with it, in the Sierra Club. Muir secured President Roosevelt's approval of the plan when the two hiked together in Yosemite Valley in 1903. When the issue finally came before the California state legislature in 1905, Muir's personal friendship with E. H. Harriman, the president of the Southern Pacific Railroad, helped

4 Robinson is reported to have said, "It takes a crank to move the world, and I would rather be a crank than a nonentity" (Jones 1965:37).

5 The reference to Robinson's "grand devil may care right or wrong style" appears in a letter from Muir to Johnson, September 13, 1889 (Muir 1889, cited in Sierra Club Bulletin 1944). 
win that company's all-important support for the recession bill that narrowly passed that year (Jones 1965:72; Holliday 1972:10).

Here as with its other conservation activities during its first decade, the Sierra Club's efforts were confined to private lobbying built in large part on the personal connections and insider political status of Club leaders (Fox 1985). In a move emblematic of the Sierra Club's self-conception as a partner, or perhaps even an agent, of governmental agencies, the Club (with financial support from the earlier mentioned Yosemite Commission) established a Yosemite office and staffed it with an attendant who provided information to tourists while keeping an eye on local economic development activity (Cohen 1988). In 1903, President Roosevelt paid tribute to this model, and to the Club, in a speech where he noted how some of the functions of the California Forest Commission were later "replaced by the Sierra Club, a club which has done much on the Pacific Coast to perpetuate the spirit of the explorer and pioneer" (Roosevelt 1903, cited in Jones 1965:21). If up to this point the Club's insider identity and conservationist goals appeared to reconcile, the Hetch Hetchy controversy would soon put this organizational formula to a severe test.

\section{Hetch Hetchy: Insiders and Outsiders}

At the center of the conflict was a City of San Francisco plan to dam the Tuolumne River at Hetch Hetchy as means of providing water and hydroelectric power to the city. Located north of Yosemite Valley on national parkland, the Hetch Hetchy valley was chosen because of its high walls and narrow exit, the very features that were said to distinguish it as one of the most dramatically scenic spots in the Sierra Nevada mountains. The reservoir, its supporters argued, would not only ensure a stable and relatively inexpensive source of water to the city but would also free it of powerful water and energy monopolies (Cohen 1988:22). The plan gained momentum in the wake of the San Francisco earthquake and the subsequent fire, whose widespread damage some blamed on the city's inadequate water supply (Turner 1991:67).

Led by Muir, the Club's board of directors came out in emphatic opposition to the project in fall 1907 and wrote to the Secretary of the Interior (whose permit was necessary for the project to proceed): "The vital interests of the nation at large" ought not be sacrificed so as "to save a few dollars for local interests"(Jones 1965:96). In casting the issue in terms of a conflict between the national interest in preservation and local economic "interests"-note the plural-those in the Sierra Club who headed the campaign hoped to gain a national constituency for their effort. As a byproduct of this strategy, taking a stand on this issue became a test of loyalties for 
those in the Club for whom local, rather than national, affiliation was of ultimate concern. Leading the opposition was Vice President Olney, who held to the belief that public policy considerations justified Hetch Hetchy's sacrifice and that the Club ought not to mobilize against the plan. Personally disheartened by growing dissent within the Club, Muir seriously considered resigning his presidency, as well as his membership (Cohen 1988:26).

In 1909, Muir's allies in the Club formed a separate organization, the Society for the Preservation of National Parks, to spearhead a national Hetch Hetchy Valley preservation campaign. Muir was the new society's president, but Will Colby, a mining lawyer who would play a leading role in the Sierra Club for years to come, carried most of the work, much of it behind the scenes because Colby's law firm was headed by a leading supporter of the dam (Jones 1965:98). A number of Sierra Club directors likewise took part, and the group's advisory council included nationally known conservationists from across the country. Rather than the Sierra Club, it was under the name of the Society that Muir and his associates campaigned against the Hetch Hetchy dam, primarily through pamphlets that they broadly distributed to congressmen, newspaper editors, women's clubs, and cooperating conservation organizations across the country.

Against the very real threat that internal disagreement on Hetch Hetchy would split the organization, the Society was conceived as means of insulating the Sierra Club from the campaign. But the strategy failed when, ignoring the formal distinction between the Sierra Club and the Society (which shared both offices and Muir's presidency), the San Francisco Call, in a December 1909 article headlined "Enemies Harming the City," accused the Sierra Club of "lending its influence to an attack designed to do the city incalculable harm" (San Francisco Call 1909a:9-10, cited in Jones 1965:109). Prompted by Olney, within a few days the Call published a second article quoting leaders in the Sierra Club "who have taken emphatic exception to any attempt to commit the organization to a policy antagonistic to the City" (San Francisco Call 1909b:17-18, cited in Jones 1965:109). No longer able to avoid a showdown, the board of directors decided to put the Hetch Hetchy question to the entire membership for a vote to "settle it once and for all" (Jones 1965:111). Of the 750 ballots returned (out of 1,300 members), 589 sided with the "desire that the Hetch Hetchy Valley should remain intact and unaltered," whereas 161 "favored the use of Hetch Hetchy as a reservoir for a future water supply for San Francisco" (Jones 1965:115). Following their defeat, 50 of the members who supported the reservoir resigned from the Club; Olney was among them (Cohen 1988:27). Backed by this mandate, Muir and Colby redoubled their letter- 
writing campaigns and other efforts aimed at building a national coalition against the project. In addition, they proposed a compromise in the form of an alternative location for the reservoir (Cohen 1988:29) - a solution very much in keeping with the era's conception of conservationist organizations as consultant to government on how to balance development and conservation. Ultimately, however, it was all for naught. In December 1913, Congress passed and President Wilson signed into law a bill allowing for the construction of the Hetch Hetchy dam inside Yosemite National Park.

In retrospect, the prominence of the Hetch Hetchy controversy colors the early years of the Sierra Club as more politically active than the historical record supports, as the Club's activism on Hetch Hetchy proved to be the exception to the pattern that it would establish. The group did not again engage in public campaign against a proposed development project until the 1950s, and its activist stance on Hetch Hetchy appeared to be largely the product of Muir's force of personality. Robinson and Muir, the men who pushed the early Sierra Club toward a more politically adversarial role, were after a fashion, "outsiders" already set apart through personal temperament and geographical distance (both lived outside the San Francisco-Oakland area). This contrasts with the situation of a man such as Colby, who-notwithstanding his strong commitment to the cause-avoided a more visible role in order to protect his professional position and relationships.

Few if any of those who first formed and joined the Sierra Club expected that their obligations as members or leaders of this Club would put them in conflict with professional, political, or social allies. As indicated by the articles of incorporation that they drafted, they came to the Club primarily to "enjoy" the mountains and each other's company, and to "solicit the cooperation of the people" on behalf of conservation (Cohen 1988:9). The assumption that such cooperation would indeed be forthcoming depended, in turn, on their own understanding of conservation as an efficient, development-friendly agenda supportive of, rather than antagonistic to, economic development goals. ${ }^{6}$ When Hetch Hetchy put

${ }^{6}$ The historian Samuel P. Hays describes the essence of the conservation movement during that time as "rational planning to promote efficient development and use of all natural resources. The idea of efficiency drew these federal scientists from one resource task to another, from specific programs to comprehensive concepts. It molded the policies which they proposed, their administrative techniques, and their relations with Congress and the public .... The popular view that in a fit of pessimism they withdrew vast areas of public lands from present use for future development does not stand examination. In fact, they bitterly opposed those who sought to withdraw resources from commercial development. They displayed that deep sense of hope which pervaded all those at the turn of the century for whom science and technology were revealing visions of an abundant future" (1959:2-3). 
this consensualist assumption to the test, Sierra Club members were confronted with a choice between what until then were complementary objects of allegiance and sources of personal and public identity.

\section{5-1946: The Partnership Era}

Muir died in 1914, a year following the Hetch Hetchy defeat. With the passing of Muir and many of the college professors who founded the Club, a new generation of leaders, comprising mostly engineers and businessmen, came to the helm, rising mostly through the Club's outdoor activities. The World War I era was associated with a stronger nationalist focus within the American conservationist movement, in and out of the Sierra Club. In 1919, the Sierra Club Bulletin quoted with approval President Roosevelt's statement (first made in 1908 at the Governors Conference on Conservation) that "the conservation of our national resources is but part of another and greater problem ... the problem of national efficiency, the patriotic duty of insuring the safety and continuance of the nation" (Sierra Club Bulletin 1919:432).

By this time, federal conservationist agencies had already been established, partially through the efforts of groups such as the Sierra Club. The Forest Service was established under the U.S. Department of Agriculture in 1905, and the National Park Service (NPS) was established in 1916. The NPS's first director was Stephen Mather, a mountaineer, Sierra Club member, and close friend of a number of Club leaders (Cohen 1988:45). The Club's relations with the Forest Service were even tighter, as the Forest Service between the 1920 s and early 1950 s relied on the Club to lobby for increased congressional appropriations and to represent its interests before other federal agencies, commodity users, the state, and local interests (Schrepfer 1997:126). In a practice that spoke to the nature of the link between the Club and these agencies, the Forest Service and NPS chief administrators served during the interwar years as honorary vice presidents of the Sierra Club, while Sierra Club directors regularly served on the Forest Service's advisory board (Schrepfer 1997:125). This partnership relationship was further cemented through professional connections and personal friendships forged on mountain trails. The leaders of the Sierra Club, the Forest Service, and the NPS belonged to the same social milieu, knew and trusted each other, and shared common understandings of the meaning of conservation and its compatibility with economic development goals. This manner of cooperative, interest group-agency relations accorded with Progressive Era conceptions of administration as an apolitical, expertise-driven process. Under this model, citizen groups, rather 
than advancing particularistic interests, served to assist agencies by offering specific forms of expertise-as yet devoid of the "capture" stigma that would soon attach to this mode of interconnection.

Although the Club did undertake some conservationist work, primarily through behind-the-scenes lobbying for the expansion of national parks, its activities during the interwar period focused primarily on its first, and in the minds of its members, primary goal: "to explore, enjoy, and render accessible" (Cohen 1988:56).

\section{6-1968: Transformation Pains}

As mentioned before, European fascism helped precipitate a shift toward greater pluralism in the United States. This entailed a twofold process in which the previously condemned "interests" were legitimated, while the earlier cooperative relationship between groups and the state became an object of criticism. Intertwined with this was the rise of post-New Deal challenges to the progressive belief in administrative autonomy and governmental expertise. The individual most responsible for bringing these ideas into the Club was David Brower, a longtime outings leader who became editor of the Sierra Club Bulletin in 1946.

Almost immediately afterward, Bulletin readers could detect a shift in emphasis away from an earlier focus on hiking and recreation and toward greater attention to wilderness protection (Cohen 1988:123). More important, the tone with regard to conservation issues became newly strident. When the Forest Service announced in 1946 a proposal to develop a ski resort in the pristine San Gorgonio Primitive Area in southern California, Brower asked rhetorically in a Bulletin article, "Can a conservation organization place the construction of ski facilities, or any development above wilderness?" (Cohen 1988:86-87). At one level, the question pertained to the group's stance in a particular controversy, but more fundamentally, it asked rhetorically what it meant to be a conservation organization, seeking to redefine the term as inherently more activist and confrontational than it had been in previous decades.

Brower had used the article to take public a division regarding this proposed site within the Club's board of directors. Opposing a plan that the Forest Service had proposed cut against established partnership relations between the groups. Moreover, prominent members of the board did not see ski resorts as incompatible with the Sierra Club's conservationist goals.

The Club's president during that time was Bestor Robinson. A prominent California lawyer and enthusiastic outdoorsman, Robinson had joined the Club in 1929 and first became director of the Club in 1933, a position he would occupy until 1963 (Cohen 
1988:67). Robinson was a longtime member of the Forest Service Advisory Committee and was an avid skier. His view on the San Gorgonio matter was that the Club had no business opposing the Forest Service's plan. As he would years later explain, "I had no use at all for the argument that there was something superior in the wilderness use and that the [resort] skiers should be considered a second class use" (Cohen 1988:85). By the late 1950s, Robinson and Brower, who would become the Club's first executive director in 1952, stood for opposite conceptions of the organization's identity.

The San Gorgonio controversy resulted in a compromise whereby the board of directors suggested an alternative site for a Sierra ski resort, Mineral King, a place that they described as "(p)robably the most spectacular site for commercial development on the west slope of the Sierra" (Cohen 1988:88). The practice of offering an alternative site dated in the Club to the Hetch Hetchy controversy, where it had failed. The method was tied to a conception of the role of the organization as an expert on how to balance development and preservation, rather than an absolutist advocate on conservation. The outcome ultimately fit with the Club's longstanding cooperative relationship with the Forest Service; yet in retrospect, the San Gorgonio story foreshadowed impending transformations in relations between the two organizations. Two-and-a-half decades later, the Sierra Club would challenge the planned resort in Mineral King before the U.S. Supreme Court (Sierra Club v. Morton 1972).

By the early $1950 \mathrm{~s}$, two interrelated developments would combine to seriously strain relations between the Club and the Forest Service: (1) increased logging within the national forests (prompted by a rise in demand for lumber in the wake of the postwar housing boom and a change in the Forest Service leadership and personnel) (Cohen 1988:188; Schrepfer 1997); and (2) a change in the public's expectations regarding the role that conservationist groups ought to play and the legitimacy of close connections between government agencies and such groups, i.e., the rise of the "capture" thesis. This change was brought home to the Sierra Club when it found itself under attack for its complacency regarding Forest Service plans to log a small stand of Jeffrey pine in a scenic area near Mammoth Lakes in the eastern Sierra.

When local residents protested that the logging would destroy the area's scenic value and harm the local tourist industry, the Forest Service defended the operation as sanitary logging - the removal of disease-prone trees that could be hazardous to hikers. Challenging this claim, a local resident by the name of John Haddaway retained an independent entomologist who declared the forest healthier than most. Charging the Forest Service with 
"strategic deceit," Haddaway blasted the agency's close connection with conservation groups such as the Sierra Club as infiltration aimed at averting trouble "at the start by a soothing word" (Schrepfer 1997:133). What was earlier a political ideal of close cooperation between agencies and the state was beginning to transform into a public relations liability.

Stung by the criticism, Brower soon took up Haddaway's cause. Suspecting that the Forest Service was under the influence of a local lumber company, Brower described its proffered justification for the logging as "blatant dishonesty" and publicly circulated a history of the controversy and local residents' accusations (Schrepfer 1997:133, 1983:106). This was a fundamental departure from the tone and tenor of relations between the Forest Service and the Club until then. A number of Club directors responded with evident dismay. Notwithstanding general agreement with Brower on the questionable wisdom of logging the particular site or the practice of "sanitary logging" as such, a number of directors took strong issue with Brower's insinuation that the Forest Service acted deceitfully or out of ill motivation. Alex Hilderband, one such director, found it necessary to come to the defense of the Forest Service's "able, sincere, and dedicated" men and warned Brower not to intervene in matters of policy where substantial disagreement existed among professional experts (Schrepfer 1983:106). As a form of compromise, the board of directors conveyed to the Forest Service its "serious doubts as to the wisdom or the necessity of the degree of cutting proposed" (Schrepfer 1997:137). Ignoring this advice, the Forest Service went ahead with the logging plan, further reinforcing the budding militancy of Brower and others within the Club's professional staff and deepening the division between them and the much more conflict-averse board of directors.

As these transformations were happening behind the scenes, the Sierra Club was helping to orchestrate a high-profile public campaign against a government-planned development, its first since the by-then mythologized Hetch Hetchy days (Gottlieb 1993:41). As at Hetch Hetchy, at issue was a dam that threatened dramatic landscapes within the boundaries of a national park (Dinosaur National Monument). It was largely for the purpose of coordinating this campaign that Brower was appointed executive director in 1952. Brower's efforts in this campaign were divided into two parts: the first was aimed to familiarize and educate the public with the area at stake through rafting trips in which hundreds took part as well as through films and photographs; the second, more explicitly political, consisted of a national letterwriting campaign, newspaper ads, congressional lobbying, and testimony before congressional hearings. 
A number of factors seemingly converged to encourage the Sierra Club to adopt a more visible and activist role in this instance. The first was the change not only in view of the role of groups in the postwar era, but also a revived attention to conservation (Gottlieb 1993). The second was the obvious parallel to Hetch Hetchy, which evoked symbolic resonance in the organization, such that even those who did not relish the fight would have had a hard time opposing Sierra Club involvement. Finally, it was important that the agency in charge of the project was the federal Bureau of Reclamation, as it had had little prior connection with the Sierra Club (as opposed to the Club's longstanding partner, the Forest Service). The latter fact made it easier for Brower to challenge the Bureau of Reclamation in public, most dramatically during a congressional hearing where, in sharp departure from the organization's longstanding deferential stance, he challenged the Bureau of Reclamation's own supporting calculations regarding rates of evaporation from the planned reservoirs (Turner 1991:145).

This incident notwithstanding, the overall tenor of the campaign remained remarkably nonadversarial (even congressional opponents made note of Brower's politeness). The campaign ended with a compromise that Brower would come to regret: Following the longstanding pattern, the Club gave its consent to the construction of a dam in Glen Canyon, a remote area in southern Utah perhaps more spectacular than Dinosaur in the eyes of the relatively few conservationists who had ventured far enough to see it (Schrepfer 1983:104). However, Glen Canyon lacked the protective status of a national park. As such, Club director Alex Hilderbrand, an engineer in charge of underground research for the Standard Oil Company, argued that the Club should not oppose "sound reclamation projects that did not invade the parks or wilderness area" (Schrepfer 1983:105). Decades later, Hildebrand held to this view:

You have to compromise. The merit is rarely all on one side even though some people like to pretend it is. The case for building Glen was much better than the case for building Dinosaur. The case against Glen didn't involve existing national parks or monuments. (Cohen 1998:178)

Growing, but until then largely hidden, tensions between the directors and Brower came into the open in 1959. In December that year, the Board made public its displeasure with Brower's increasingly confrontational posture when-under the heading "Relations with Agencies"-it issued the following two guidelines: (1) those speaking on behalf of the Club were not to make statements that directly or implicitly criticized "the motives, 
integrity, or competence of an official or bureau"; and (2) when reporting on controversial conservation matters, both sides of the issue ought to be represented (Cohen 1988:237). The move appeared to reflect a mixture of concerns: personal loyalty on the part of some directors to the Forest Service and individuals within it; underlying consensual sensibilities regarding proper organizational "manners"; and, most explicitly, the worry that in assuming a more contentiously political identity, the Club risked having the Internal Revenue Service (IRS) revoke its tax-exempt status under the Federal Regulation of Lobbying Act of 1946 (which the Supreme Court upheld in 1954) (Cohen 1988:163-64).

Partially to avert a change in its tax status, the Club joined in creating a separate lobbying organization, Trustees for Conservation, under the logic that it could take on more explicitly political functions without compromising the fiscal position of the Club as such. Importantly, however, it appears that by that time there was at least some constituency within the Club's membership advocating a more activist conservationist orientation. Out of concern that these members would question the organization's decision to hide behind such a separate organizational front, Richard Leonard, then the Club's president, explained in a Bulletin article that "with no privileged status to protect," the Trustees could "take the message of conservationists directly and vigorously to Congress" (Leonard 1955:3, cited in Cohen 1988:166). Yet protecting the Club's tax-exempt status seems to have been only part of the rationale behind this move. The goal of ensuring donors' capacity to deduct contributions to the Club from their taxes would have equally been served had the Club adopted Brower's preferred solution: officially registering as a lobbyist (losing its tax status) while channeling donations, earmarked for activities other than lobbying, to a separate foundation. Instead, two considerations appeared to favor the Trustees' option: (1) the protection it offered did not require the Club to take on the (politically tainting) identity of a lobbyist or interest group; and (2) the solution restricted Brower's formal capacity to engage in lobbying activities while being compensated by the Club (Cohen 1988:165-66). ${ }^{7}$

The long-anticipated IRS action finally came to pass in 1966, triggered by the Club's mobilization against yet another dam - this

${ }^{7}$ Notwithstanding the creation of the Trustees, the Club created in 1960 a separate fundraising organization, the Sierra Club Foundation, in the event that contributions to the Club as such could no longer be deducted. Michael McCloskey provided the following explanation as to the strategic considerations behind the creation of the foundation: "At that time, there was a notion that we should have three institutions proceeding in a somewhat parallel way. ... The thought was that the trustees would play a very out front role in overt lobbying, that the club would take some risks in doing lobbying, but it would not set out to lose its tax deductible status, but that if we did, the foundation had been formed and was there to be used" (McCloskey 1983:135). 
time at Marble Bridge near the Grand Canyon. In taking this measure, however, the IRS unintentionally provided the Club with a public relations and membership recruitment boon (Gottlieb 1993:44). Against the backdrop of the Civil Rights movement and Vietnam War protest, the Johnson Administration's displeasure with the Club helped the organization reshape its by-now politically detrimental "insider" status and consensualist reputation.

The Club's Grand Canyon campaign marked a distinctive shift away from the compromise-oriented problem definitions of the past toward a more absolutist conservationist agenda. As noted, ever since Hetch Hetchy, the Sierra Club had coupled its opposition to particular projects with its consent (or even its own proposals) for alternative sites that were often themselves located within scenic locales outside protected national park boundaries. Departing from this precedent, Brower led the Club to adopt a position opposing all hydroelectric facilities in scenic locales and backed this goal with direct action tactics and a more strident rhetorical tone (Gottlieb 1993:44). The public appeal of this more contentiously political style was evident in exponential membership growth in the aftermath of the Grand Canyon campaign, as the membership roster grew from 39,000 in June 1966 to 78,000 in June 1969 (Cohen 1988:362). Among some of the Club's older members and leaders, however, there was great resistance toward the nature and level of conflicts that absolutist conservationist agendas of this type by necessity entailed.

A dispute over a plan by Northern California's Pacific Gas \& Electric Company (PG\&E) to build a cluster of nuclear power plants on the central California coast precipitated a dramatic showdown between competing factions in the Club (Turner 1991:179). Persuaded that "it was not the role of the Club to fight progress," some Club leaders worked closely with PG\&E to find a suitable alternative location, ultimately settling on Diablo Canyon on a deserted stretch of the central California coast (Cohen 1988:369). The board of directors endorsed the Diablo site in May 1966 as consistent with the "club's long tradition, and its most effective practice, of urging the selection of alternative sites" (Cohen 1988:367). The compromise, the Club's president William Siri further argued, would also encourage PG\&E to continue consulting with the Club in the future (Cohen 1988:367). However, vociferous dissent within the board resulted in a decision to put out the Diablo Canyon plan for the entire membership to ratify during the upcoming elections for the board of directors.

Seventy percent of the membership voted to uphold the Diablo Canyon plan; at the same time, a number of new directors who were opposed to the plan were elected to the board, which subsequently passed a resolution withdrawing its support. An all- 
out battle ensued over the Club's obligation to abide by its earlier commitment and over the trustworthiness of PG\&E (Cohen 1988:370). Well beyond the particular issue at stake, the Diablo Canyon dispute catalyzed long-brewing divisions on proper organizational goals and tone, Brower's leadership style, and the Club's place and response to a rapidly rising environmental movement. When the dust settled, PG\&E (which never depended on the Club's consent in the first place) built the Diablo Canyon nuclear power plant, and Brower lost his executive director position (Turner 1991).

As noted before, tensions between the board of directors and Brower over matters of both substance and style were evident at least since the board passed the 1959 "Relations with Agencies" resolution, dubbed by Brower the "gag rule." These tensions would persist and deepen over the next decade in a process that would ultimately lead to Brower's departure. ${ }^{8}$ It was under the watch of the next executive director, Michael McCloskey, thatwith the structure of the Club's relations with government agencies fundamentally altered-litigation would become a defining organizational instrument for the Sierra Club.

\section{The Club in Court}

From Warren Olney and Will Colby on, lawyers served visible leadership positions in the Club and made their expertise available on matters such as contracts, copyright, tax, and the like. Building on this model, Richard Leonard, a San Francisco lawyer and past president of the Sierra Club, established in 1963 the Conservation Law Society, an organization devoted to the provision of low-cost legal services to conservationists. But the Society was not conceived as an instrument of conservationist litigation, and Leonard himself was known for his criticism of some of Brower's confrontational methods (Cohen 1988:392). Both the legal committee and the Society, however, were later retooled and drawn upon to launch Sierra Club v. Morton (1972), the case that redefined the Sierra Club's identity and cast it as a major environmental law player (Turner 1990:13). Generous financial assistance from the Ford Foundation contributed to this transformation, most importantly in facilitating the 1970 establishment of the Sierra Club Legal Defense Fund. But in view of the organization's longstanding access to legal

8 Brower's opponents focused their criticism on his allegedly poor fiscal management and autocratic leadership style (Cohen 1988). McCloskey explained the conflict in terms of a history of conflict between Brower and old-guard directors that led him to adopt a "damn-the-torpedoes attitude" rather than the "give and take" attitude necessary for successful leadership of a membership organization such as the Sierra Club (McCloskey 1983:95). 
expertise, it was apparently not for lack of legal and financial capacity that the Club prior to the 1960s chose not to litigate.

The first time the Club took part in a conservationist suit was in 1962, when it joined a legal challenge that another conservationist organization, the National Parks Association initiated in defense of Rainbow Bridge National Monument against rising waters from the Glen Canyon Dam. The failure of that suit, largely on lack of standing grounds, is among the primary pieces of evidence supporting the floodgate model (Sierra Club Bulletin 1962). But the significance of this example cannot be understood in isolation from the anomalous circumstances leading to the case. The National Parks Association, rather than the Sierra Club, was the central plaintiff in the Rainbow Bridge lawsuit. Brower succeeded in gaining the board of directors' consent to the Club's participation in the suit, but the decision was seen at the time as "an unusual action given the outlook of the board, for it stepped up the degree to which the Club was willing to directly confront government officials." 9 Furthermore, working in Brower's favor was the fact that Glen Canyon, the source of the threat to Rainbow Bridge, had been built with the Club's consent as part of the Dinosaur campaign compromise. And as part of that deal, the U.S. Department of the Interior had pledged "to take whatever steps were necessary to protect" Rainbow Bridge (Schrepfer 1983:105).

The legitimacy of adversarial political or legal action was still unresolved within the Sierra Club of the early 1960s. In an effort to persuade reluctant factions of the need to move in a more activist direction, the Sierra Club Bulletin published in 1964 an article entitled "Controversy as a Saving Force." That article argued that

[t]he role of the private conservation organization is the willingness to accept controversy as an important part of its activity and to take advantage of basic philosophical controversy to stimulate a public concern that will combat both agency complacency and public apathy. (Sierra Club Bulletin 1964:15)

At the same time, the article was careful to acknowledge the cost that such conflict might exact of those accustomed to more cooperative modes of interaction. Against this backdrop, the Second Circuit was preparing to hear an appeal from an ad hoc group of New York citizens in the Scenic Hudson case.

David Sive, a New York attorney and chairman of the Atlantic chapter of the Club, was on the team of lawyers who shepherded the Scenic Hudson appeal, but the Club itself avoided any visible involvement in the controversy until after the legal victory

9 This is according to Phil Berry, who was close to Brower at the time and would later play pivotal role in the Club's legal transformation (Cohen 1988:240). 
(according to Brower, he allocated $\$ 1,500$ to help Sive stay on the case, only to be scolded by the board; see Brower 1989). However, things changed rapidly after that. By the time the Federal Power Commission held a second set of hearings in 1966 (following the Second Circuit's remand), the Club submitted a brief on the beauty of the Hudson River at Storm King, and Brower testified before the commission (Cohen 1988:392).

The Scenic Hudson case indeed proved to be a turning point in the evolution of the Sierra Club, but for reasons deeper than the broadening of standing as such. Against the backdrop of a nationally publicized (and celebrity-studded) campaign to stop Consolidated Edison from building the power plant at Storm King, the case helped legitimate an emergent model of adversarial environmental activism. In swinging the courthouse doors wide open, Judge Hays's Scenic Hudson opinion (1965) had made it more difficult for those in the Club who were determined, until then, to hold on to the earlier cooperative model.

Scenic Hudson and the social movement-like mobilization behind that case were not, of course, freestanding events; they were part of an era of growing antiwar protest and civil rights activism. With this a new environmentalism came to the fore that differed from its conservationist precursor in both the scope of its agenda and its explicitly confrontational stance. Whereas established environmental groups such as the Sierra Club and Audubon Society had long restricted their missions to the protection of natural resources and scenic landscape (showing little interest in problems of pollution or the built urban environment), concerns about risk from chemicals - crystallized after the 1962 publication of Rachel Carson's Silent Spring - were central to the rise of 1960s environmental activism. The new environmentalism challenged not only the older organization's aesthetic and/or economicresource framed problem definitions but also the consensual style with which these definitions intertwined. Unlike resource conservation, or even the preservation of beautiful scenery, protection of human health was a goal inherently less amenable to compromise. In the wake of Scenic Hudson, the Club attracted many lawyers who began to bring lawsuits on the Club's behalf on a pro bono basis. At the same time, the Club's volunteer legal committee, which until then was exclusively occupied by the legal business of the Club, began to take on a number of conservation issues, including the Forest Service's revival of a plan to construct a ski resort in Mineral King (McCloskey 1983:141-42). ${ }^{10}$

${ }^{10}$ By 1967, a staff member could write "Last year, the New York lawyers began joining the club at such a rate that I was afraid we were going to become the New York Bar Association" (Schrepfer 1983: 164). 
Mineral King is an area at the southern end of the Sierra near Sequoia National Park that the Club, back in 1947, had suggested as an acceptable alternative for a proposed ski resort in the San Gorgonio mountains. In 1965, the Forest Service returned to that idea and published a request for proposals from developers with an interest in the project. For the following year there ensued within the Club a rancorous debate on whether the Club was obligated, by virtue of its earlier compromise, to go along with the plan (Turner 1990:9). But in the end, a majority on the board opted to oppose the planned resort (McCloskey 1983:169). ${ }^{11}$

In 1968, the board authorized "appropriate legal proceedings to protect the Mineral King area and Sequoia National Park" (Cohen 1988:392, emphasis added). The Forest Service-the Club's traditional partner - would be its opponent in its first substantial lawsuit. Gaining time was the suit's main strategic rationale, according to McCloskey:

We did hope that the litigation would produce a delay to give us time to gear up political action. At the time we filed the suit, we were on the ropes. The Forest Service was about ready to issue permits and start construction. (McCloskey 1983:168)

The Club offered a number of procedural challenges to the project, but the brief's primary novelty derived from its failure to assert any vested interest, on the part of the Club or its members, as grounds for standing. Instead, casting itself as a "private attorney general" of the type the Scenic Hudson court endorsed, the Club argued that it was entitled to bring the suit by virtue of its conservationist organizational purpose. In opting for this rather risky strategy, the Club sought to position itself as a representative of a larger public interest, rather than the parochial interests of its members. As McCloskey recounted, "We clearly didn't think we were going to all of this trouble just on behalf of ourselves or the Sierra Club. We had the sense that we were the agents of the natural world in pursuing its welfare" (1983:172-73). But the strategy backfired when (against prevailing expectations) the Supreme Court upheld the Ninth Circuit's denial of the Club's standing for lack of showing that the ski resort would in any fashion harm the Club or its members (Sierra Club v. Morton 1972). ${ }^{12}$

11 The board unified in opposition to the project once the Forest Service issued the Disney Corporation in October 1966 a permit to build what the company promised to be "the world's largest ski resort," a development several orders of magnitude greater than what the 1947 Sierra Club had in mind (Turner 1990:9).

12 The Club later amended its complaint, adding detailed arguments on likely injury to the Club (as well as adding individual plaintiffs with more specific recreational or property interests in the area). The political and legal battle would drag on for another five years; in 1978, the area was added to Sequoia National Park, and a ski resort in Mineral King was never built (Turner 1990:23). 
The case, especially Justice Douglas's dissenting view of the Club as a proper advocate for the rights of trees and nature as such, was a symbolic victory and a major publicity boon, helping to project an aggressive organizational identity much at odds with the old Sierra Club. Inside the organization, however, significant ambivalence remained. On the one hand was pressure (supported by a large majority of the membership) to follow the more adversarial and activist example set by new environmental movement groups; on the other hand was a much smaller (but influential) group of older members and leaders deeply discomfited by the Club's changing orientation. McCloskey addressed this concern in a 1971 editorial:

The changing nature of the Sierra Club's program is producing some distinctive challenges. . . Our legislative proposals, in the main, reflect a growing conflict over priorities in society. This conflict pits the Club, and much of the environmental movement, in a contest of will and strength against most elements of the American economy and the government agencies allied with them ... . Sometimes, these industries, and even our members associated with them, accuse us of being "irresponsible and unfactual." (McCloskey 1971)

These divisions may have played a part in the decision to create the Sierra Club Legal Defense Fund as a separate organization, with its own board of trustees, budget, and staff. Tax considerations, the conventional explanation for this decision, undoubtedly played a part in this decision (Turner 1995). But the relationship between the tax considerations and the separation of the main organization from the Defense Fund was indirect. The Sierra Club had already created a separate Sierra Club Foundation after its taxexempt status was rescinded in order to facilitate the collection of tax-deductible money for nonpolitical purposes. The Foundation provided a potential alternative means of ensuring that donations to the Legal Defense Fund were tax deductible. But the Foundation was overseen by a board of trustees comprising former presidents of the Sierra Club who were steeped in earlier consensualist conceptions of the Club and its mission (McCloskey 1983:136). When asked why the Defense Fund was spun off as a separate organization, McCloskey (who was executive director at the time of the decision) did not mention tax considerations. He instead attributed the decision to a desire to prevent a "bottleneck of our decision making processes" (McCloskey 1983:143), an apparent reference to the consensualist proclivities of the Sierra Club Foundation. The Legal Defense Fund reflected and importantly stimulated greater emphasis on both litigation and lobbying; nevertheless, the Club as a whole "remained reactive 
and often wary of the developments reshaping the mainstream groups during the early 1970s" (Gottlieb 1993:149).

In 1971 , the Club conducted a national survey of its members regarding their background, reasons for joining, and attitudes on matters of organizational style and purpose. In response to the question "[a]re lawsuits and lobbying appropriate Club activities?" two-thirds of the respondents strongly agreed, whereas only 5\% thought litigation inappropriate (Coombs 1972:38). ${ }^{13}$ Of the Club's 140,000 members at the time, about half the members had belonged for two years or less; nine percent had joined prior to 1960. Recent members joined to support conservation activities, while most long-term members originally joined to participate in outdoor activities. Most likely, it was primarily out of their ranks that the $5 \%$ of the respondents who disapproved of litigation came.

The alienation felt by some such older members at the time is palpable in a cover note that Alberta Reed Huber, the widow of past Club president Walter Huber, attached to her answers to a questionnaire that the Club's History Committee sent her in 1972. She wrote,

I doubt if my answers will be of any value to you. I am one of the "oldtimers" who still belong but do not go along with it ... . I have not been in sympathy with the Sierra Club for a number of years. (Cohen 1988:61)

Mrs. Huber first met her husband on a Sierra Club outing, and the organization for decades hence was an integral and important aspect of their lives, but by the early 1970 s she and her generation shared little with the rapidly transforming Sierra Club. As the following account suggests, old-timers in a similarly transformed SPNI would, most likely, sympathize.

\section{Society for the Protection of Nature in Israel: From Corporatism to Quasi-Pluralism}

From its inception, the Israeli state was constructed on a political terrain marked by precarious national (Jewish versus Arab) and religious (secular versus orthodox) fault lines. Political mobilization along these divisions was, however, long made rare by the absence of civil associations standing outside the state and the national partnership it claimed to represent. A 1979 study of Israeli interest groups by Yishai (1979) invoked SPNI to epitomize the then-

13 The published results do not specify how opposition to litigation and length of membership correlated. But the speculation of such a correlation gains support from the fact that older members (more than the younger ones) expressed support for the idea that the Club should put greater emphasis on outings than on conservation (Coombs 1972). 
entrenched corporatist culture of Israeli political groups during that time. The organization, she writes, "prides itself for being one of 'deeds' (i.e. positive actions) rather than of 'pressure' by spreading the love of nature among many young Israelis" (Yishai 1979:210). More than two decades later, the same author once again relied on SPNI to illustrate Israel's drastic pluralist transformation. This "formerly compliant" group, she writes, is "now applying militant strategies to counter political decisions" (Yishai 2001:149). On the eve of its fiftieth anniversary, the SPNI mirrors larger transformations in Israeli society. It is no longer the corporatist group it once was, but throughout the 1990 s its organizational identity was still in a process of transformation, with different factions pulling in opposite directions. The lingering hold of previous partnership relations is reflected in the relative marginality of litigation in the organization's strategic repertoire during the 1990 s. $^{14}$

\section{Organizational and Ideological Foundations}

During the 1949 meeting of the Israeli Zoological Society, a German-born professor named Heinrich Mendelssohn suggested forming a committee for nature protection. Mendelssohn had arrived in Tel Aviv in 1935, and his work thereafter focused on a study of bird life in the Huleh wetlands in the northern part of the country. The area had been targeted for reclamation ever since the 1920s, and Mendelssohn expressed concern beginning in the 1930 s over the loss of this ecologically rich environment. The reclamation plans kicked into high gear with the establishment of the state, and it appears that this fact was the immediate impetus behind Mendelssohn's initiative (Tal 2002:129). The committee assembled a small number of academics who took upon themselves the task of advising the Israeli government on matters of conservation, most importantly the Huleh reclamation plan. But their proposal for setting aside a subsection of the area as an untouched nature reserve failed to persuade, and by 1958 the Huleh was almost completely drained. ${ }^{15}$ Beyond offering its advice, the Committee invited a group of newspaper journalists

${ }^{14}$ This section draws primarily on two historical accounts of SPNI. The first is Alon Tal's Pollution in the Promised Land (2002). The second is a commemorative booklet that SPNI published upon its fortieth anniversary (Regev 1993). I rely on the latter source for two distinct purposes. First, it is a source of historical facts on personalities and organizational activities; for this purpose I use it as a secondary source. Second, I quote it as a primary source of evidence on the ways in which the organization views its own history and seeks to explain itself to the outside world. In addition, the section relies on newspaper accounts and interviews with three individuals who witnessed some of the events described.

15 In 1993, the Israeli government announced a plan to reflood the Huleh in an effort to correct what by then had come to be understood as both an economic and ecological mistake. 
on a tour of the area, in an effort to draw some public attention to the issue. But this was the scope of their "public campaign." Subsequent to this experience, the need for a stronger institutional and political conservationist presence became evident, and the Society for the Protection of Nature was born.

Two men led this initiative: Amotz Zahavi, a graduate student of Mendelssohn's whose research focused earlier on the Huleh area; and Azariah Alon, a teacher and youth group leader from a northern kibbutz. Veterans of the 1948 War of Independence, they both epitomized the Israeli elite of the time. They were the consummate insiders, and the organization they would create would be an insider's organization, despite the fact that its mission and structure were hardly native to Israel. It was the German-born Mendelssohn who pushed his student Zahavi to create the group and who shepherded it through its first decade, offering both crucial financial resources and expertise (Tal 2002).

In undertaking this initiative, Mendelssohn was, most likely, inspired himself by the ideas and organizational models of the German Naturschutz movement. The parallels between the German conservationist movement and SPNI begin with the organization's use of the term nature protection (Naturschutz) in its name and continue with its early quasi-administrative functions. Most important, however, SPNI followed the German model in linking conservationist ideologies with nationalism. From its earliest days, at least some within the Naturschutz movement invoked nationalist rationales in support of conservation. Seeing nationhood as the bond between a people and its land, the Volkisch strain of the Naturschutz movement promoted conservation as a duty to protect "Germanic Nature rather than Nature as a whole" (Dominick 1992:22, emphasis in original). A similar intersection between nationalist and conservationist ideology marked SPNI's early years.

In 1952, Mendelssohn's Nature Protection Committee joined members of neighboring Kibbutz Alonim ("oaks" in Hebrew) in lobbying against the plan to log an old oak grove as part of the development of a new town. They offered the following argument in support: "We have sacrificed our efforts and blood so as to prevent the destruction of these ancient oaks by our Arab neighbors, there is no justification now that they should be uprooted by the state of Israel" (Regev 1993:16). Knowing and loving the land are intertwined duties within the Zionist worldview; yet the concept of land in this connection is one with a distinct nationalist thrust. It extends well beyond nature into all that infuses the Israeli landscape with Jewish national significance, including archeological sites indicative of Jewish historical roots and new settlements establishing a renewed Jewish presence. Even industrial development (long heavily subsidized by the state) 
constitutes part of the combined physical/spiritual entity Israelis call "the land" (no qualifier needed). In innumerable songs, Israeli culture celebrates mountains, streams, trees, and flowers, and has long imbued hiking with a patriotic, at times even paramilitary, connotation.

This is crucial to understand the inherently nationalist meaning of SPNI's "nature protection" mission, a raison d'être that left no room for conflict with the state through the articulation of a separate environmental agenda. Since nature mattered only to the extent that it was nationally incarnated, its protection could hardly trump developmental projects whose contribution to nationbuilding was deemed greater. ${ }^{16}$ And because Zionist ideology imbued "the act of building and transforming the (mostly desert) environment" with social revolutionary meaning, for decades after the state's founding, few developmental projects in practice failed to meet the requisite national contribution threshold (De-Shalit \& Talias 1994:288; Vogel 1999).

\section{4-1973: The Partnership Years}

SPNI's founding convention took place in July 1954 in Oranim, the kibbutz movement's educational institute near Haifa. The bulk of those who attended were members of kibbutzim whom Alon had recruited. In a memo that he circulated in January 1954, Alon proposed several sets of goals for the new organization, including recruiting a large number of members who would then help disseminate nature protection values, most importantly through active measures to prevent "hunting and destruction of animals, and injury to trees and plants, especially with respect to uncommon species; creating public support for the passage of nature protection legislation; and publishing educational materials" (Regev 1993:116). ${ }^{17}$

The group's organizational style had a distinct, kibbutzinspired, informal, nonhierarchical flavor (Tal 2002:133). The leadership was made up of consummate insiders with extensive and cross-cutting connections, embedded within the intimate army, kibbutz, and university networks that were the early Israeli state. SPNI's membership grew to approximately 15,000 within three

16 Yiftachel and Segal (1998) refer to the symbiosis between environmentalist and Zionist agendas in Israel in the following terms: "The authorities are interested in these lands because they are part of the State of Israel and preservation of nature is considered an Israeli-Jewish value, part and parcel of the national identity 'constructed' in recent decades .... Since the main point is control over lands, emphasizing the state as the absolute power holder, there is no difference between a military training zone and a natural reserve as long as the rules for each are given by the state and are enforced" (1998:501).

${ }^{17}$ Memo from Azariah Alon to Heinrich Mendelssohn, Amotz Zahavi, and eleven others, January 5, 1954. Reproduced in Regev (1993:116). 
years of its founding, impressive evidence of the effectiveness of these networks. But it would be incorrect to see this as indicative of a groundswell of support for the group's conservationist mission. Rather, as Zahavi explained, people joined because they, or their associates, asked them to, as a matter of interpersonal obligation more than anything else (Regev 1993:25). This fact is central to understanding the intersection between interpersonal and political connections within the early Israeli state.

It was through such connections that SPNI first gained the governmental funding it needed to survive (membership dues were a symbolic one pound). As it turned out, the Minister of the Interior, a kibbutz member himself, was a friend of Azariah Alon. A short meeting between the two sufficed to channel funds from the Ministry of the Interior to SPNI with little further bureaucratic ado or governmental oversight (Tal 2002:136). What in retrospect appears illegal or corrupt was devoid of such connotations during that time; this manner of clientelistic behavior was characteristic of Israeli political norms during those days, as SPNI saw itself and was seen as an integral element of the state itself.

In fact, SPNI functioned during its first decade in a quasiadministrative capacity. Its primary conservationist activity was managing inspection centers across the country that it operated through a cadre of municipally funded "regional workers." The goal was to protect vegetation and wildlife in scenic locales and ecologically sensitive areas against damage by hikers and hunters. "Nature protection" meant protection against damage inflicted by the Israeli public, not the developmental agendas of the state.

The quasi-administrative model had significant international precedent. The Sierra Club, as earlier discussed, had assumed a quasi-administrative function in Yosemite for a short time around the turn of the twentieth century. The German Naturschutz groups engaged extensively in similar enforcement practices during the same era in Bavaria. ${ }^{18}$ In parallel with both these precedents, SPNI lobbied the Israeli government to establish both national nature reserves and an administrative body to oversee them, a task that was completed with the 1963 establishment of the Nature Reserve Authority.

The following few years were marked by very close cooperation between the two organizations. As was the case for the Sierra Club, SPNI leaders had a say in the choice of the men chosen to head the Authority, and Alon (who took over from Zahavi as SPNI's general

18 By 1913, 2,330 "overseers" operated in Bavaria, members of private conservationist organizations whose "responsibility was to promote a Naturschutz awareness in the local area, to become familiar with the natural environment of that area, and to warn the proper authorities if any of Nature's local treasures were threatened" (Dominick 1992:50). 
secretary in 1969) served on the Authority's board between 1964 and 1976. The two organizations, in fact, went as far as to form a joint entity, named Shahar, under the direction the Authority's chairman. Their most important joint venture was a campaign aimed at reversing sharp declines in the population of many previously numerous species of wildflowers. The two organizations lobbied successfully in $\mathbf{1 9 6 5}$ for the passage of legislation declaring many varieties of endangered flowers to be protected species. Backed by this legislation, SPNI set out to redefine the picking of wildflowers (a common recreational practice until that time) as a socially unacceptable - even unpatriotic-act through a concerted educational campaign that quickly and effectively altered relevant norms and behavior. For decades hence, the successful wildflower campaign - a quintessential effort at protection against the public, rather than development interests-epitomized SPNI's identity and mission within both the organization and the Israeli public's eye.

With the creation of the Nature Reserve Authority, SPNI relinquished its quasi-administrative tasks and put education and hiking at the center of its enterprise. Primarily as means of raising funds, SPNI initiated an outing program in 1956, which grew quickly in the next few years. Tapping into the centrality of hiking within the Zionist culture of that era, SPNI came to lead outdoor youth movement seminars, military youth core treks, and eventually public school excursions. SPNI would ultimately become a primary provider of hiking and field education services to the Ministry of Education, which in turn provided a substantial portion of the organization's budget (Bar-David \& Tal 1996).

This mode of education was directed first and foremost toward love of the land, through hands-on knowledge of its geography, geology, nature, archeology, and military heritage. In undertaking this educational mission, SPNI relied to a great extent on a rotating cadre of female soldiers who spent their military service as guides in SPNI's field schools, a distinctive SPNI institution of that era. Scattered across the country, the schools were designed to impart knowledge and love of the land. To the extent that SPNI's educational mission included a conservationist component during that time, it was of the anti-flower-picking, anti-littering variety.

In the early 1970s, SPNI was for all intents and purposes a hiking organization, with a tiny percentage of its budget going toward conservationist work of any kind (Tal 2002). One of the few conservationist matters on which it was active at the time revolved around a power station planned for the base of the Taninim stream, one of central Israel's few relatively unpolluted waterways. In response to the proposal, Alon published a position paper calling for an alternative, less ecologically damaging location, and 
in April 1972, an SPNI rally drew 500 people to the Taninim site, receiving broad coverage in the Israeli press. As a consequence, the plant was moved from Taninim to an already polluted stream at nearby Hadera (Tal 2002). The Hadera location, while protecting the Taninim stream and its associated nature reserve, nonetheless mars to this day tens of miles of central Israel's coastline with the visual impact of its smokestacks, hundreds of feet high.

The controversy centered on the plant's location, not its construction per se. As noted, similar relocation solutions were the outcome of a series of Sierra Club campaigns from the mid-1940s to the mid-1960s, which represented a transitional period toward the Club's more pluralist identity. The Sierra Club's transition was more or less complete by 1972, when the Stockholm Conference on'the Global Environment helped spread the environmental movement's message across the globe. In SPNI, processes reminiscent of the Sierra Club two decades before were about to unfold.

\section{Quasi-Corporatism: 1974-1984}

Environmental ideas trickled into Israel during the early $1970 \mathrm{~s}$ largely through American and other English-speaking immigrants and visitors whose numbers increased in the years following the Six-Day War. A second vehicle was Israel's participation in international environmental bodies, beginning with the Stockholm conferences (which Alon attended). In 1973, the Environmental Protection Service (a forerunner of a later Ministry of the Environment) was established. ${ }^{19}$ Within SPNI, environmental concerns gained increased attention with the establishment of a new Department of Nature Conservation in 1974.

Tensions between SPNI's longstanding nationalist-conservationist agenda and what some within it viewed as infiltrating American ideologies came to the fore when a group of SPNI guides in a Sinai field school sought to publish a booklet containing Hebrew translations of excerpts from foundational texts of the American environmental movement. Their request was summarily rejected by Alon because, as he noted, the texts slated for inclusion were "not of ours," and by implication, constituted an American import with little relevance to SPNI's "love of the land" agenda.

19 Like scores of other countries essentially devoid of domestic environmental constituencies, Israel sent a delegation to the Stockholm conference, held in June 1972. Later that summer, the decision to create a new agency that would coordinate and supervise environmental affairs in Israel was made, and one year later an Environmental Protection Service was established under the auspices of the Prime Minister's office (Mandelbaum 1977). 
The group published the booklet on its own, in what may have been the first such instance in Israel, on recycled paper. But the dispute marked an end to an era in which internal agreement within SPNI regarding what is and is "not of ours" could be assumed.

More directly relevant to the issue of litigation was Alon's opposition to forging an ongoing professional connection between SPNI and an attorney who could advise it on matters of conservation (and presumably help undertake some litigation). Lawyers, he argued, were not what SPNI was about. ${ }^{20}$ Others within the group, however, had begun to see it otherwise.

The 1980s saw the entrance onto the Israeli scene of multiple and diverse new social and political organizations, partially through initiative, guidance, and, most important, financial resources offered by American foundations, both Jewish and non-Jewish. Inspired by American conceptions of pluralist democracy, these foundations worked to create the conditions for a more autonomous Israeli civil society. The emergence of American-modeled public interest groups oriented toward litigation was intimately tied to this development.

SPNI began to bring conservationist litigation during the early 1980 s. In 1982, the group brought a suit against a planned West Bank settlement slated for an area that had been declared a nature reserve by the Jordanian authorities. While opposition to West Bank settlements was not the motivation behind the suit (Tal 2002), the location may have made it an easier target for litigation in that it fell outside the quickly disappearing Israeli political consensus. Furthermore, in bringing the suit, SPNI was advancing the view that territory occupied in the 1967 war was within its purview, and may thus have been serving a nationalist goal at the same time that it challenged a particular development in the area.

\section{Quasi-Pluralism: 1984-1994}

The decade between 1984 and 1994 was marked by deep organizational ambivalence over appropriate goals and tactics for the organization. SPNI emerged during that time as an increasingly visible organization, with an environmentalist rather than national-conservationist agenda. Nevertheless, in controversies entailing direct confrontation with a substantial state or kibbutz interest, it tended to follow public sentiment rather than lead (Tal 2002). This was also true of what came to be seen as SPNI's crowning glory, the Voice of America (VOA) campaign.

\footnotetext{
20 Interview with attorney Naomi Weil, June 10, 1997.
} 
In 1985, the Israeli government agreed to a Reagan Administration request to build a massive radio transmitter (the world's largest) in the southern Arava Desert. The station was intended to transmit broadcasts to the far reaches of the Soviet Union and to counteract Soviet broadcast jamming. Slated to occupy three square miles, the station was to include 47 antennas, some 650 feet high. The project was financially lucrative for Israel, and, more important, was seen as an important contribution to IsraeliAmerican relations. SPNI's initial response was limited to a request that the project's environmental impact be considered prior to the approval of the project.

In SPNI between 1985 and 1990, opposition to the VOA plan was essentially a one-woman campaign. Bilhah Givon, a long-time SPNI employee, worked closely with the local citizens on the issue, while SPNI's leadership vacillated. Her persistent pressure ultimately paid off when in 1990 SPNI announced its outright opposition to the project (Tal 2002:165). Actual mobilization against the project had begun from among residents in the villages around the planned area, who were concerned primarily about potential danger from electromagnetic radiation. In 1989, they brought a suit that sought to disqualify the siting decision on procedural grounds, arguing that the VOA transmitter was not a national issue and should only be reviewed at a local or district planning council (where the influence of the affected residents was presumably greater). The Israeli Supreme Court rejected the claim in February 1990.

Once on board, SPNI took two crucially important moves. The first was to file a second lawsuit together with the local residents, this time challenging the adequacy of the environmental impact process. In addition to the lawsuit itself, an important strategy of SPNI was to enlist environmental groups in the United States and elsewhere in the world to mobilize against the plan, ultimately recruiting over one hundred ten groups. In a 1991 decision, the Israeli Supreme Court temporarily enjoined the project pending the completion of a more complete Environmental Impact Statement (EIS) (Rabinovich 1991). This bought SPNI and its allied American nongovernmental organizations crucial time, during which SPNI's executive director traveled to the United States and addressed a Congressional committee on the VOA issue. Environmental concerns, coupled with a changed geopolitical context in the post-Cold War era, ultimately persuaded the Clinton Administration to cancel the plan.

The case marked a transition for SPNI. For the first time, the organization had set out against what was defined as a national interest by the government, and its use of both litigation and alliances with outside groups set this case in opposition to the 
organization's longstanding tradition of national partnership. Yet the state interest that was being challenged was hardly a matter of consensus; the Israeli Ministry of the Environment and 74 Knesset members had actively declared their opposition to the plan. ${ }^{21}$

Internal divisions that had delayed SPNI's action in this case did not disappear with the VOA controversy, and in 1991-1992, a new state-sponsored development project divided competing factions in SPNI. The Trans-Israel Highway was a planned three hundred-kilometer toll road expected to cut across much of the country. Though the project would profoundly alter the Israeli landscape and the direction of its future land use and transportation policies, it quickly passed through the various pertinent planning approvals with little public attention or debate. Through the first half of the 1990s, the road was a political nonissue in Israel, as few there thought to challenge what the government termed a "national project" with important transportation, economic, and social benefits.

SPNI's then executive director, Yoav Sagi, was present when the National Planning Commission called for the preparation of a master plan for the road, but Sagi made little effort to slow the planning process in 1992. The following year, SPNI's own landscape preservation think tank offered qualified support for the plan. Within SPNI's Department of Nature Conservation (DNC), there was significant frustration with this policy. In fact, the head of the Department met with the board of directors of the Israel Union for Environmental Defense (IUED) and encouraged them to take action against the road (Tal 2002).

The turn to IUED was indicative of the loss of SPNI's monopoly on conservation issues in the Israeli political environment. Among the manifestations of Israel's associational revolution at the start of the $1990 \mathrm{~s}$ was a sharp rise in the number of environmentally active organizations (Bar-David \& Tal 1996). Of these, it was the NRDC-modeled IUED that most directly challenged SPNI's previous hegemony - in parallel fashion to the influence that groups such as the EDF and the NRDC earlier had on the Sierra Club. The impact of changes on the outside was, as in the case of the Sierra Club, divisions on the inside. Tensions between the DNC and SPNI's leadership intensified, with some in the DNC threatening to resign. They won this battle in 1995 when SPNI announced its opposition to the road and began to mobilize against it, but too late for it to have any effect (Tal 2002:178).

SPNI marked its fortieth anniversary in 1994 in the shadow of these divisions. A commemorative historical account that SPNI

\footnotetext{
21 SPNI press release, February 19, 1993 (in Hebrew, on file with author).
} 
published in honor of the occasion offered the following summary of the group's conservationist work:

SPNI is not a cabal of insane extremists screaming against the message of progress. Its power derives from its ability to partake of the nation, contribute to improvements in the standard of living and advance new ideas and initiatives. From this it derives its right to carry the fight for [the preservation of] the landscape, the environment and nature. (Regev 1993:74)

The choice of language suggests that there was at this point at least some public constituency for more adversarial modes of activism. In a newspaper article devoted to the anniversary, Alon responded to the claim that the group's affiliation with the establishment impeded its capacity to act by saying, "I don't know that it's a bad thing. I think that part of our success is that we work together with the IDF [Israel Defense Forces], government ministries and others. We never wanted to play alone, but to involve others" (Collins 1994:3)

\section{5-1997: Transformation Pains}

A sharp reduction in the Ministry of Education's support for SPNI's school programs, together with growing competition from other outings and tourist services, left the organization during the mid-1990s with a severe deficit and an urgent need to reduce its operating costs. But the crisis also presented an opportunity for long-submerged matters of organizational goals and identity to be placed squarely on the table. The result was a far-reaching organizational overhaul, massive budget cuts, and the elimination of approximately 200 SPNI staff positions (close to $20 \%$ of the staff) (SPNI 2002). A major focus of this reform consisted of a drastic revamping of SPNI's 26 field schools-institutions with deep symbolic resonance for many Israelis within and outside SPNI. In what some would perceive as a direct attack on the organization's commitment to imparting "love of the land," the reformers imposed new efficiency-based criteria on the management of these schools, subordinating their mission to a paramount environmental protection goal (SPNI 1996).

Tensions between these competing "love of land" and environmental organizational visions came to a head during the 1997 elections for the board of directors. Until that time, elections to the board had been a sleepy event about which few of the thousands of SPNI's members cared and even fewer bothered to take part. But the elections were turned into a referendum on the organization's future course with the departure from SPNI (in August 1997) of the "Uri Mimon scouting clubs." 
The clubs were initially created by a group of friends as a memorial for a soldier killed in the 1973 war, a tribute deeply rooted in Israel's "love of land" culture. In 1976, they officially affiliated with SPNI, which created a new Youth Division to manage them. At the time of SPNI's fortieth anniversary, at least some in the organization considered the clubs among the "most appealing, colorful, unique and successful SPNI enterprises" (Regev 1993:75). ${ }^{22}$ Yet in 1997, the Mimon clubs withdrew from SPNI and reestablished themselves as a separate organization. The split followed a mix of financial, organizational, and ideological complaints. At the most fundamental level, however, their departure was the product of the ideological distance that the SPNI leadership had traveled from its nationalist conservationist origins. As they explained, "the Green goals of SPNI and the educational mission of the Scouting Clubs" were not the same (Rinat 1997). With a promise "to act on behalf of SPNI's true goals, first among them the educational activities such as those provided by the hiking clubs," a slate of candidates sympathetic to the scouting clubs competed during the 1997 elections (Rinat 1997).

Under the name "SPNI Faithful," the incumbent leadership cast itself as defender of the group's authentic values and traditions against economically motivated developers - highlighting connections between its opponents and real estate and business interests - in particular Dror Hoter-Yishai, then the head of the Israeli bar association and a man with extensive development interests. It was largely through that angle that the Israeli media, and through it the larger public, framed and responded to the controversy. Hoter-Yishai, who was among the original founders of the Mimon clubs and had maintained close connections with the project ever since, vehemently denied that his real estate interests had anything to do with the clubs' departure from SPNI and their role in the elections - a claim backed by long list of scientists, educators, and long-time Mimon club members who mobilized behind the slate (Rinat 1997).

On the day of the elections in January 1998, thousands of SPNI members came to Tel Aviv from all parts of the country to cast their ballots, $90 \%$ of them in support of the incumbent SPNI Faithful slate (Collins 1998). One interpretation of this showing would be to see it as indicative of a groundswell of popular support for SPNI's newfound environmental agenda. But environmental consciousness probably had little to do with the scope of the response. Rather, it appears that a sense of affiliation with SPNI's older nationalist self

${ }^{22}$ During the first part of 1997,300 separate hiking groups, comprising 3,700 members, took part in this project (SPNI 1997). 
was the impetus that led many to come. This is perhaps best evident in the active mobilization of the kibbutz movement on behalf of the cause. For Israelis ambivalent about weakening national bonds, SPNI remained a powerful symbol of a younger, unified, and to some, more idealistic state. SPNI was able to tap into this symbolic capital even if, ironically, it was the Mimon clubs whose vision better accorded with the SPNI's original statist identity.

SPNI's annual report for 1997, published in the midst of this internal struggle, depicts an organization at the center of environmental controversies spanning the Red Sea, the Dead Sea, Jerusalem's forests, and Tel Aviv's beaches. The same report, for the first time, mentions lawsuits brought during the previous year. They concerned issues pertaining to the management of nature reserves, open space preservation, and, primarily, coastal private development (SPNI 1997:7). Nevertheless, litigation remains a relatively rare instrument within SPNI. In 1998, the SPNI board rejected a proposal by the DNC to create an internal legal division and opted instead to continue the practice of retaining outside attorneys to represent SPNI in legal proceedings. The argument offered was that in-house lawyers would not be able to match the service provided by the high-caliber external attorneys on whom SPNI relied. ${ }^{23}$ But the decision also offered the SPNI board a tool to ensure that the DNC would give careful financial and other consideration each time it weighed an option to sue. As Tal writes, " $[t]$ he fact that SPNI's legal advisers remain external and charge per case cannot help but influence the alacrity with which the organization initiates litigation" (2002:152).

The decision amounted to a conscious choice not to develop the support structures that would allow greater integration of litigation strategies into the organization. It suggests that notwithstanding far more distant relations between SPNI and the state, SPNI's transformation to pluralism is not, as of yet, complete.

\section{Partners No More}

The importance of both favorable legal structures and material resources to the capacity of groups to litigate is hardly in doubt. Rather than challenging this argument, this article takes issue with the implicit notion that, given the necessary legal and material resources, groups will invariably opt to litigate to promote their agendas. Instead, it finds the root of variations in the litigation propensity of groups in the structure of relations between such

${ }^{23}$ Interview with Emily Silverman, SPNI Department of Nature Conservation, Tel Aviv, July 1999. 
organizations and the state. The contemporary term interest group assumes as a matter of definition the organization's pluralist identity and legal-adversarial inclination. But to answer why organizations earlier failed to litigate, we must first understand whether and when they in fact became such "interest groups." Through parallel historical analysis of institutional transformation within these two originally consensualist conservationist organizations, this study challenges the implicit notion that outside the locked courthouse gates there have long stood interest groups ready and eager to litigate.

As discussed in the introduction, the understanding that the structure of interpersonal relations (rather than the capacity for litigation as such) affects the transformation of disputes is an uncontroversial tenet of sociolegal scholarship. In much greater dispute is the claim that relations-whether at the individual or collective level-that are not face-to-face can similarly explain reluctance to litigate. This is because in these cases it is harder to understand where the value of such relations may lie, or what the source of their capacity to define personal and political obligations might be. Willingness to subsume organizational aims to a larger common good is nonsensical under a pluralist system in which the collective interest is itself defined through unbridled pursuit of individual and group goals. Within the pluralist framework, absence of requisite institutional conditions, such as appropriate standing rules, is thus a more persuasive and internally consistent explanation for the historical absence of litigation from the strategic repertoire of most groups. Expectations of such sacrifice are, however, integral to the partnership frameworks within which corporatist groups operate.

The power of such expectations is particularly salient within the Israeli context. Discussions of Israeli environmental history often invoke a popular Zionist pioneering song by the poet Nathan Alterman: "We shall build you, our beloved country, and make you beautiful; we shall cover you with a robe of concrete" (Alterman 2000:302; Regev 1993; De-Shalit \& Talias 1994:290). But the key as to why environmental ideologies and their attendant legal adversarial strategies were so slow to take root in Israel is, perhaps, encrypted in a different line within the same song: "We love you homeland; what we haven't as yet given, we shall give" (Alterman 2000:302). In an Israel where the terms of membership have demanded of individuals' willingness to subsume all for the greater national good, the notion that environmental values ought to trump state-defined national interests has long been incongruous, if not inconceivable.

Distinctive political, military, and demographic conditions during Israel's first decades account for the particular depth of 
SPNI's solidarity with the state. But even in the United States, the history of the Sierra Club suggests a link between similar -if more muted-ideological influences and consensualist patterns of behavior. In both instances, evidence that the groups' consensualism was rooted in partnership ideologies - rather than deficient opportunity structures--comes from the tenor and logic of arguments that adherents of consensualist strategies put forth during vociferous moments of intraorganizational debate. These conflicts, often pitting generational cohorts against one another, expose processes of dispute transformation that usually remain internal to individuals in private contexts; revealed in this way is a progression through which organizational identity, preferences, and commitments - rather than strategies as such-come to be redefined. Such processes predictably leave behind "old-timers" such as Alberta Reed Huber (in the Sierra Club) and Azariah Alon (in SPNI).

In both the United States and Israel, the expectation that the best-established groups would have initiated a strategy of litigation is not borne out. Instead, upstart environmental law groups such as the EDF and the NRDC led the U.S. environmental movement to court, while the older groups followed suit only after some delay and, at times, reluctantly. A similar pattern is evident in Israel where, instead of SPNI (the country's oldest and largest conservation group), a younger group (modeled after the NRDC) was the first Israeli environmental organization to use legal advocacy as its primary organizational strategy (Morag-Levine 2001).

Like the Audubon Society, both the Sierra Club and SPNI did add litigation to their organizational repertoire, and the Sierra Club ultimately became a major litigator. Yet in both instances, the floodgate model fits observed organizational behavior poorly. Rather than revealing an eagerness to embrace novel political and legal opportunities for adversarial activism - as institutional capacity theories of interest group litigation would predict - these organizations engaged in protracted and sometimes wrenching debates over the shift to adversarialism. Evident in these debates are deep divisions on matters of organizational identity, the importance of personal and political loyalty, and the legitimacy of challenging the developmental agenda of the state. The depth and tenor of these disagreements suggest that impediments to the adoption of litigation strategies for both groups lay deeper than mere organizational "habits" or inertia. The older generation's discomfort with the groups' subsequent turn toward all manner of adversarial action suggests that what was at stake was the very rationale behind their affiliation with the group. Their palpable sense of loss in the face of a dissipating partnership with the state detracts from the persuasiveness of institutional inertia as 
explanation for the delay in the adoption of litigation strategies by the two groups.

The Sierra Club of 1970 and SPNI of the late 1990s assumed an institutional identity that was sharply at odds with their former selves. A new generation of leaders and members reshaped the previous organizational mold to fit their own environmental mission and pluralist notions. They inherited from their predecessors an organizational shell, history, and name, but placed these in the service of transformed organizational ends. In doing so, they were prompted by the rise of new environmental ideologies and new conceptions of the properly adversarial function of interest groups - the ideas that, around the same time, contributed to judges' liberalization of such groups' standing to sue. In retrospect, this doctrinal change and other increases in groups' capacity to sue offer a plausible explanation for their earlier absence from the courts. But in taking for granted the groups' earlier adversarial inclinations, this explanation assumes what is in fact the core question at stake-one capable of resolution only through historical investigation of the actual tenor of the groups' relations with the pertinent state bureaucracies, over time.

This study has suggested a corollary between individual-level dispute transformation and that which occurs in the realm of interest groups. In both the individual and the group cases, an understanding of litigation behavior must not focus on the moment of litigation alone, but requires longitudinal study of the processes leading to that event, most importantly of the structure of the pertinent relations. When understood as the outcome of such processes of institutional transformation, contemporary, and perhaps global, growth in levels of interest group litigation emerge as a more significant development than the floodgate model seems to suggest. Rather than mere tactical adaptation to the opening of hitherto blocked legal opportunities, the judicialization of politics attests to deeper processes of separation between civil society and the state.

\section{References}

Alterman, Nathan (2000) “Shir Boker [Morning Song]," Pizmonim V'Shirei Zemer, Part II, $2 d$ ed. Tel Aviv: Ha-Kibbutz Ha-Meuhad.

Andrews, Richard N. L. (1999) Managing the Environment, Managing Ourselves. New Haven, CT: Yale Univ. Press.

Arian, Asher (1993) "Israel: Interest Group Pluralism Constrained," in C. S. Thomas, ed., First World Interest Groups. Westport, CT: Greenwood Press.

Bar-David, Shirli, \& Alon Tal (1996) Harnessing Activism to Protect Israel's Environment: A Survey of Public Interest Activity and Potential. Tel Aviv: Adam Teva V'din-The Israel Union for Environmental Defense. 
Bentley, Arthur F. (1967 [1908]) The Process of Government. Cambridge, MA: Belknap Press of Harvard Univ. Press.

Berry, Jeffrey M. (1977) Lobbying for the People: The Political Behavior of Public Interest Groups. Princeton: Princeton Univ. Press.

Berry, Phillip S. (1997) Sierra Club President, 1991-1992: The Club, The Legal Defense Fund, and Leadership Issues, 1984-1993. Sierra Club History Series, Regional Oral History Office, Bancroft Library, University of California, Berkeley.

Black, Donald (1976) The Behavior of Law. New York: Academic Press.

Brickman, Ronald, Sheila Jasanoff, \& Thomas Ilgen (1985) Controlling Chemicals. Ithaca, NY: Cornell Univ. Press.

Brower, David (1980) Environmental Activist, Publicist, and Prophet. Sierra Club History Series, Regional Oral History Office, Bancroft Library, University of California, Berkeley.

- (1989) "Letter to Doug Scott, Conservation Director, Sierra Club, July 13," http://www.igc.apc.org/icc370/brower.htm.

Cannon, Julie (1973) "New Standing for the Environment," 58 Sierra Club Bulletin 14-16.

Clemens, Elizabeth S. (1997) The People's Lobby. Chicago: Univ. of Chicago Press.

Coglianese, Cary (1996) "Litigating Within Relationships: Disputes and Disturbances in the Regulatory Process," 30 Law E Society Rev. 735-65.

Cohen, Michael P. (1988) The History of the Sierra Club 1892-1970. San Francisco: Sierra Club Books.

Collins, Liat (1994) "SPNI Marks 40 th Anniversary," The Jerusalem Post, 9 June. (1998) "Traditionalists Sweep to SPNI Victory," The Jerusalem Post, 16 Jan.

Coombs, Don (1972) "The Club Looks at Itself," 57 Sierra Club Bulletin 35.

Cortner, Richard C. (1968) "Strategies and Tactics of Litigants in Constitutional Cases," $17 \mathrm{~J}$. of Public Law 287.

De-Shalit, Avner, \& Moti Talias (1994) "Green or Blue and White? Environmental Controversies in Israel," 3 Environmental Politics 273-94.

Dominick, Raymond H. (1992) The Environmental Movement in Germany. Bloomington: Indiana Univ. Press.

Dotan, Yoav, \& Menachem Hofnung (2001) "Interest Groups in the Israeli High Court of Justice: Measuring Success in Litigation and in Out-of-Court Settlements," 23 Law E Policy 1-27.

Ellickson, Robert C. (1991) Order Without Law. Cambridge: Harvard Univ. Press.

Engel, David M. (1984) "The Oven Bird's Song: Insiders, Outsiders, and Personal Injuries in an American Community," 18 Law E Society Rev. 551.

Epp, Charles R. (1998) The Rights Revolution. Chicago: Univ. of Chicago Press.

Epstein, Lee (1985) Conservatives in Court. Knoxville: Univ. of Tennessee Press.

Epstein, Lee, \& Joseph F. Kobylka (1992) The Supreme Court and Legal Change. Chapel Hill: Univ. of North Carolina Press.

Felstiner, William L. F., Richard L. Abel, \& Austin Sarat (1980-1981) "The Emergence and Transformation of Disputes: Naming, Blaming, Claiming...," 15 Law E Society Rev. 631.

Fox, Stephen (1985) The American Conservation Movement. Madison: Univ. of Wisconsin Press.

Gottlieb, Robert (1993) Forcing the Spring. Washington, DC: Island Press.

Greenhouse, Carol (1986) Praying for Justice: Faith, Order and Community in an American Town. Ithaca, NY: Cornell Univ. Press.

Haley, J. O. (1978) "The Myth of the Reluctant Litigant," 4 J. of Japanese Studies 359-90.

Hamilton, V. Lee, \& Joseph Sanders (1992) Everyday Justice. New Haven, CT: Yale Univ. Press.

Harris, Richard A., \& Sidney M. Milkis (1996) The Politics of Regulatory Change: A Tale of Two Agenices, 2nd ed. New York: Oxford Univ. Press. 
Hays, Samuel P. (1959) Conservation and The Cospel of Efficiency: The Progressive Conservation Movement, 1890-1920. Cambridge: Harvard Univ. Press.

Hjelmar, Ulf (1996) The Political Practice of Environmental Organizations. Aldershot, England: Avebury.

Holliday, J. S. (1972) "The Politics of John Muir," 57 Sierra Club Bulletin 10-13.

Jones, Holway R. (1965) John Muir and the Sierra Club. San Francisco: Sierra Club.

Kagan, Robert (2001) Adversarial Legalism. Cambridge: Harvard Univ. Press.

Kagan, Robert A., \& Lee Axelrad (2000) Regulatory Encounters. Berkeley: Univ. of California Press.

Katzenstein, Peter (1985) Small States in World Markets. Ithaca, NY: Cornell Univ. Press.

Kawashima, T. (1963) "Dispute Resolution in Contemporary Japan," in A. von Mehren, ed., Law in Japan. Cambridge: Harvard Univ. Press.

Kelman, Steven (1981) Regulating America, Regulating Sweden. Cambridge: MIT Press.

Koshner, Andrew Jay (1998) Solving the Puzzle of Interest Group Litigation. Westport, CT: Greenwood Press.

Lempert, Richard O., \& Joseph Sanders (1986) An Invitation to Law and Social Science: Deserts, Disputes, and Distribution. New York: Longman.

Leonard, Richard M. (1955) "We Defend the Parks," 40 Sierra Club Bulletin 3. Cited in Cohen, Michael P. (1988) The Hisiory of the Sierra Club 1892-1970. San Francisco: Sierra Club Books.

- (1975) Mountaineer, Lawyer, Environmentalist. Sierra Club History Series, Regional Oral History Office, Bancroft Library, University of California, Berkeley.

Lijphart, Arend, \& Markus M. Crepaz (1991) "Corporatism and Consensus Democracy in Eighteen Countries: Conceptual and Empirical Linkages," 21 British J. of Political Science 235-46.

Macaulay, Stewart (1963) "Non-Contractual Relations in Business: A Preliminary Study," 28 American Sociological Rev. 55.

Mandelbaum, Paulette (1977) Pollution and the Making of Public Policy: Israel, 1965-1975. Ph.D. dissertation, Department of Political Science, Columbia University.

March, James G., \& Johan P. Olsen (1989) Rediscovering Institutions: The Organizational Basis of Politics. New York: Free Press.

McCloskey, Michael (1971) "Editorial," 56 Sierra Club Bulletin 2.

- (1983) Sierra Club Executive Director: The Evolving Club and the Environmental Movement, 1961-1981. Sierra Club History Series, Regional Oral History Office, Bancroft Library, University of California, Berkeley.

Migdal, Joel S. (1993) "Civil Society in Israel," in E. Goldberg, R. Kesaba, \& J. Migdal, eds., Rules and Rights in the Middle East. Seattle: Univ. of Washington Press.

Morag-Levine, Noga (2001) "The Politics of Imported Rights: Transplantation and Transformation in an Israeli Cause-Lawyering Organization," in A. Sarat \& S. Scheingold, eds., Cause Lawyering and the State in a Global Era. New York: Oxford Univ. Press.

Muir, John (1889) Letter to Robert Underwood Johnson, September 13. Cited in Sierra Club Bulletin (1944) "The Creation of Yosemite National Park," 29 Sierra Club Bulletin 50.

- (1895) "A Plan to Save the Forests," Century, February, cited in Miller, Char (2001) Gifford Pinchot and the Making of Modern Environmentalism. Washington, DC: Island Press; p. 137.

New Israel Fund (1998) http://www.nif.org/rights/factciv.html.

O'Leary, Rosemary (1993) Environmental Change: Federal Courts and the EPA. Philadelphia: Temple Univ. Press.

Olson, Susan M. (1990) "Interest-Group Litigation in Federal District Court: Beyond the Political Disadvantage Theory," $52 \mathrm{~J}$. of Politics 854.

Orren, Karen (1976) "Standing to Sue: Interest Group Conflict in the Federal Courts," 70 American Political Science Rev. 723-41. 
Orren, Karen, \& Stephen Skowronek (1995) "Order and Time in Institutional Study: A Brief for the Historical Approach," in J. Farr, J. S. Dryzeck, \& S. T. Leonard, eds, Political Science in History: Research Programs and Political Traditions. New York: Cambridge Univ. Press.

Peretz, Don, \& Gideon Doron (1997) The Government and Politics of Israel. Boulder: Westview Press.

Petracca, Mark P. (1992) "The Rediscovery of Interest Group Politics," in M. P. Petracca, ed., The Politics of Interests. Boulder: Westview Press.

Powell, Walter W. (1991) "Expanding the Scope of Institutional Analysis," in W. W. Powell \& P. J. DiMaggio, eds., The New Institutionalism in Organizational Analysis. Chicago: Univ. of Chicago Press.

Rabinovich, Abraham (1991) "Opponents of VOA Station Win Two-Year Construction Respite," The Jerusalem Post, 30 July.

Ramseyer, J. Mark (1988) "Reluctant Litigant Revisited: Rationality and Disputes in Japan," 14 J. of Japanese Studies 111.

Regev, Ofer (1993) Arbaim Shnot Pricha [Forty Years of Blossom]. Tel Aviv: Society for the Protection of Nature in Israel.

Rinat, Tsafrir (1997) "The True Ones and the Underminers: Preliminary Summary," Ha'Aretz, 30 July (in Hebrew).

Rodgers, Daniel T. (1987) Contested Truths. New York: Basic Books.

(1998) Atlantic Crossings. Cambridge: Harvard Univ. Press.

Roosevelt, Theodore (1903) Califormia Addresses. San Francisco: The California Promotion Committee. Cited in Jones, Holway R. (1965) John Muir and the Sierra Club. San Francisco: Sierra Club.

Rosenberg, Gerald N. (1991) The Hollow Hope: Can Courts Bring About Social Change? Chicago: Univ of Chicago Press.

San Francisco Call (1909a) "Enemies Harming the City," 11 Dec., 9-10. Cited in Jones, Holway R. (1965) John Muir and the Sierra Club. San Francisco: Sierra Club. - (1909b) 12 Dec., 17-18. Cited in Jones, Holway R. (1965) John Muir and the Sierra Club. San Francisco: Sierra Club.

Scheppele, Kim Lane, \& Jack L. Walker, Jr. (1991) “The Litigation Strategies of Interest Groups," in J. L. Walker, ed., Mobilizing Interest Groups in America: Patrons, Professions, and Social Movements. Ann Arbor: Univ. of Michigan Press.

Schmitter, Phillippe (1974) "Still the Century of Corporatism," 36 Rev. of Politics 85-131.

Schrepfer, Susan R. (1983) The Fight to Save the Redwoods. Madison: Univ. of Wisconsin Press.

(1997) "Establishing Administrative 'Standing': The Sierra Club and the Forest Service, 1897-1956," in C. Miller, ed., American Forests: Nature, Culture, and Politics. Lawrence: Univ. of Kansas Press.

Sellers, Jefferey M. (1995) "Litigation as a Local Political Resource: Courts in Controversies over Land Use in France, Germany and the United States," 2 Law E Society Rer. 475-517.

Sierra Club Bulletin (1919) "Editorial," 10 Sierra Club Bulletin 431-32.

(1944) "The Creation of Yosemite National Park: Letters of John Muir to Robert Underwood Johnson," 29 Sierra Club Bulletin 49-60.

(1962) "Rainbow's Day in Court," 4 Sierra Club Bulletin 91.

(1964) "Controversy as a Saving Force," 48 Sierra Club Bulletin 15.

Society for the Protection of Nature in Israel (SPNI) (1996) National Environmental Campaigns. Internal report, March.

- (1997) Annual Report 1997 (in Hebrew). Tel Aviv: SPNI.

(2002) "Facing 2000," http://www.spni.org/about/show_item.asp?leveled=331,

2 March.

Tal, Alon (2002) Pollution in the Promised Land. Berkeley: Univ. of California Press. 
Tate, C. Neal, \& Torbjörn Vallinder (1995) The Global Expansion of Judicial Power. New York: New York Univ. Press.

Thelen, Kathleen, \& Sven Steinmo (1992) "Historical Institutionalism in Comparative Politics," in S. Steinmo, K. Thelen, \& F. Longstreth, eds., Structuring Politics. Cambridge: Cambridge Univ. Press.

Truman, David (1971) The Governmental Process: Political Interests and Public Opinion, 2nd ed. New York: Alfred A. Knopf.

Turner, Tom (1990) Wild by Law: The Sierra Club Legal Defense Fund and the Places It Has Saved. San Francisco: Sierra Club Books.

(1991) Sierra Club: 100 Years of Protecting Nature. New York: Harry N. Abrams, Inc.

(1995) "Sierra Club and Sierra Club Legal Defense Fund: Common Names, Common Aims, yet Distinctly Different," 80 Sierra 18.

Vogel, David (1986) National Styles of Regulation. Ithaca, NY: Cornell Univ. Press. (1999) "Israeli Environmental Policy in Comparative Perspective," 5 Israel Affairs 245.

Wiarda, Howard J. (1997) Corporatism and Comparative Politics. Armonk, NY: M. E. Sharp. Wilkins, Thurman (1995) John Muir: Apostle of Nature. Norman: Univ. of Oklahoma Press.

Williamson, Peter J. (1989) Corporatism in Perspective. London: Sage Publications.

Yiftachel, Oren, \& Michaly D. Segal (1998) "Jews and Druze in Israel: State Control and Ethnic Resistance," 21 Ethnic E Racial Studies 476.

Yishai, Yael (1979) "Environment and Development: The Case of Israel," 14 International J. Environmental Studies 205.

(1991) Land of Paradoxes: Interest Politics in Israel. Albany: New Univ. Press.

(2001) "Israel: The End of Integration," in C. S. Thomas, ed., Political Parties \& Interest Groups. Boulder: Lynne Rienner Publishers.

Zeigler, Harmon (1988) Pluralism, Corporatism, and Confucianism. Philadelphia: Temple Univ. Press.

\section{Cases Cited}

Scenic Hudson Preservation Conference v. Federal Power Commission, 354 F.2d 608 (1965). Sierra Club v. Morton 405 U.S. 727 (1972). 
